\title{
INFLUENCE OF DIAMOX (ACETAZOLAMIDE SODIUM) UPON INNER EAR AND HISTOCHEMICAL STUDY OF CARBONIC ANHYDRASE
}

\author{
By \\ YASUO WATANABE \\ From the Department of Oto-rhino-laryngology Osaka University \\ Medical School (Director: Prof. T. Hasegawa)
}

A study was made on the influence of Diamox (acetazolamide sodium) upon inner ear tissue and inner ear fluid, for this drug has been in use for glaucoma for its depressive effect upon the intrao. cular pressure.

On an assumption of the presence of carbonic anhydrase in stria vascularis, widely recognized site of secretion of endolymph, histochemical demonstration of the enzyme was also attempted by modi. fied Häusler's method.

Materials used were human kidneys and adult normal guinea pigs and rats.

Vital transfusion fixative specimen of inner ear of adult normal guinea pigs were made $1,3,6,12$ and 24 hours respectively after the injection of 100 $\mathrm{mg} \mathrm{Kg}$ of acetazolamide sodium.
One-hour specimen showed marked dilation of capillaries of stria vascularis and twelve-hour specimen, depression of Reissner's membrane.

Decrease of sodium in endolymph was noted one hour after the injection of the substance.

When 20 micron thick, non-decalcified frozen section of cochlea, placed on a colodium menbrane, was free floated on the surface of the incubation medium according to Häusler's method, stria vascularis was positively stained to indicate the presence of carbonic anhydrase.

The same method also demonstrated the activity of carbonic anhydrase along the inner border or brush border of urinary tubule endothelia of human kidney as well as in the proximal urinary tubule endothelia of normal adult rat and guinea pig.

\section{内耳組織お゙び內耳液におよぼす Diamox (acetazolamide sodium) の影響, および 炭酸脱水酵素の組織化学的研究}

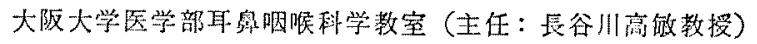 \\ 大学院学生 源部泰去
}

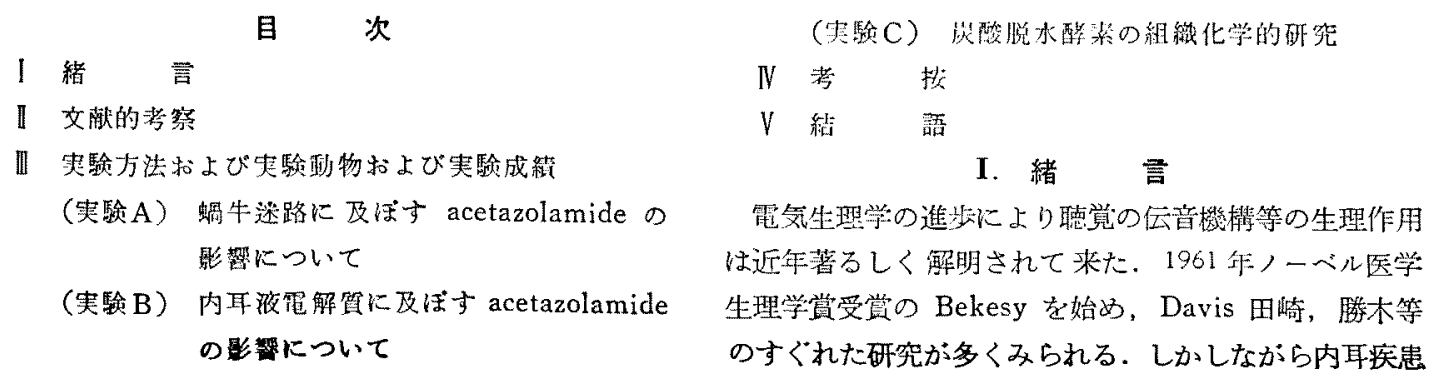


には睍代の進歩に拘らず米た原因不可のものが多い，

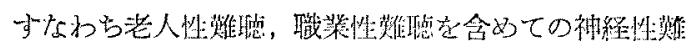

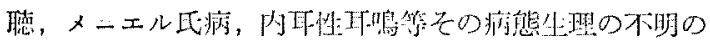
ところ少くない。

これらの問題の解明にとつて内恥需気現象の检索とと

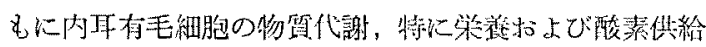

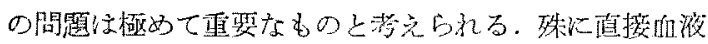
に上る物質枟送が少いと考元られる有毛綳胞にとつて内 耳液の開题は極めて重要なるの上洘克られる。

しかし，内耳液の分泌，呼败，循㻴の閭題は今日な お，譛愦があり決定されていない。

著者は Smith (1954)により明らかにせられた内外り

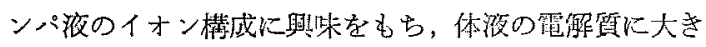
な变化を与えるとい机ている acetazolamide sodium をモルモットに投与，その内耳組䄉括よび内耳夜組成の 変化を追求，内耳物質代謝の一面を知り，また，岸酸脱 水酵装の組織化学的証明法 (Häusler 法) 起改良し内 耳の血管帯にこれを笛明したので報告する。

\section{II. 文献的考察}

内耳の組織学にはその微細な点に関しては現在なお 諸説があり，従つて内耳液の分泌，吸収の問題汇関して も古来より多くの説が述べられたが未だ結論は得られて wない.

有毛細胞への举坫扣上び酸素供給に直接関与すると考 えられる内リンパ夜の分泌に関しては Corti (1851) Schambaugh (1908) 等により血管带上り分泌さ礼ると 唱えられ，以来血管帯上り分泌するという考光は内リン ハ分必説の非心となつている。

しかし一方, Halle, Rudinger は内リンパは脳背艏液 より由来すると速べ, Gegenbauer, Siebeman, Quix, Egmond.は外りンバが内リンパの一部を供給すると考 えている.

Witttmaack（1916）は分泌洫管带，蠌旋器上皮，

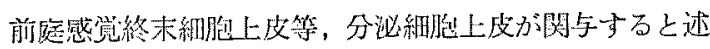

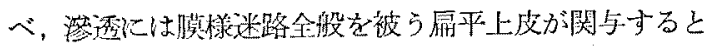
した。

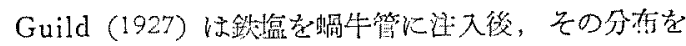

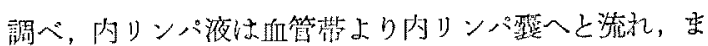

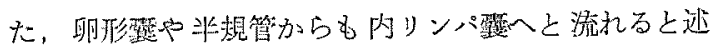

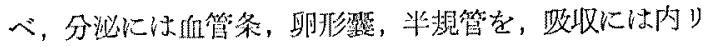
ンバ政を考光た. 1956年 Lawrence は prominentia spiralis に和いて rosette cells を発見し，この部は祭 䍩物供給源と考况られると述べた。

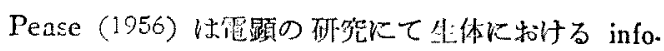
Ided basal plasma membrane $か ゙$ water transport $K$ 阙䒚与ると報告. C.A. Smith (1957) はこれをモルモ ツト血管带に認め，また電顕ミトコンドリフ像よりモル モット组管帶と prominentia spiralis に内タンパ生産 が我えられると述べた。

S.D. Erulkar (1961) 等は眼房水生成に関与する毛

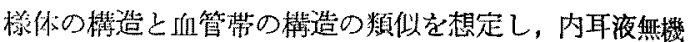
インン模成との闒連を述べた。

一方 Borghesan (1957) 恃血管帯は内リンパ分谈化 適当でない䧿造であると述ぺている。

Naftalin（1958）等は内リンパ液は外リンパ液より前 庭呰を介して由来するると述べ，血管带は管尿細管と同様 の働きをなし，伤機イオンの交换に関与すると推湘して いる.

Merle Lawrence (1960) は内リンパ夜の流れを電 気現象と結びつけ Corti-Guild の stria から分必され saccus に问つて流れ，投収されるといら説を longitudinal theory 之名付秥 Naftalin u. Harrison の前庭階 より队畃リンパ腔へ流れがあるといら説を radial theory

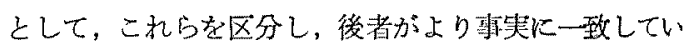
ると述べている。四収の部位に関しては更に不明のとこ ろ多く，上記，Corti，Guild 等け内リンパ露と述ぺてい る他 Quix, Egmond, Kley, Altmann, Waltner, Saxen 等は outer spiral sulcus と述へ Lindsay は頁に種タ な部位も考觉ててる。

外リンパの分泌，吸收に関しても諸説がある。年の解

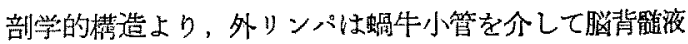
上り生じ，また蝸牛小管以外の経路，すなわち，外リン 管を介して，またクモ膜下腔から，また血管周目，脖 神経䩗間㗂を介して㩆液よりくるとも考えられている。 その啳 Kley（1951）は外リンぷは外リンパ腔自身より 生しると唱え，限外被過で形成されると推定している.

Altmann \& Waltner (1950) は内リンパり由来する と唱克る。一方，後藤（修）三宅等性外リンパ二起源説 を唱え，趾㳔拈上び血清上り生しると考克ている。吸収 つ部位に関しては，これまた不明のところ多く，近年， 切替（1961）等は兒落注入实駼拈よび venules の血管 峨造より lower spiral ligament を想定している.

内外リンパ液の組成に関しては，その量的な問题，才

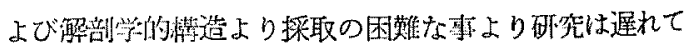
いた．僅かた，海江田（1930）が鲛を用いて，その内外 


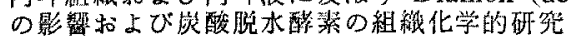

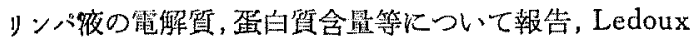

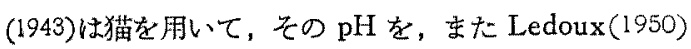
は $\mathrm{CO}_{2}$ 拉よび蛋白について報告している.

Graf u. Poretti (1950) は radioactive $\mathrm{Na}$ を用い て，内外リンパ夜への取り込みを報告し，内リンパへの 取り込るが少いと述べている。

しかしながら，内外リンバ液の電解質の特異性を明碓 そしたのは C.A. Smith (1954) である.

Smith はモルモットを用いて，その微量内外リンパ 液の無機イオンの測定を行い, 外リンパはそのイオン構 成に执いて血清子たは組織間掖に類似し，内リンパ液は 細胞内洎に類似していると報告した。この結果はCitron Exley (1956)，三宅 (1960) 等により追試されたが各研 究者の報告はその特異なる無機イオン構成に関して大略 一致をみた。 Smith の報告せるこの内リンバの高カり ウム，扣よび外リンパの低カリウムは電気生理的㯖営機 構，才なわら，CM. AP, EP 等之関連しても追求され ると到つた。

すなわち，中村 (1962) 等は内リンパ液の置換を行い， この祭，聴觉䉓気現象の变化すること学報告している，

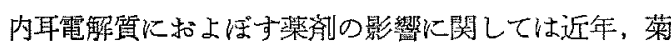
地 (1957) がピロカルピン。アドレナリン, 重曹水, 投 与時の無機イオンの変動を報告している. 芦原 (1960) はコーチゾン，ストマイ投与による内耳篦解質の変化を 報告. コーチゾンにて Na，K の低下を，ストレプトマ イシンルて Na の低下を報告した。

Wullstein (1961) はメニエル氏病の患渚で矓舅発作 が湤しく，迷路破堎術を行つた際の内耳液の電船質を計 測し, メニエル氏病に括いて, 前庭階の外りンハ液の力

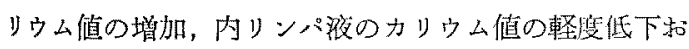
よびナトリゥムの增加傾向，および鼓室階外リンパは正 常という所見を得ている。これより彼はライスネル膜の 選択的透過性の変化を考古ている.

内耳の老人に約将組織像は Saxen u. Fieandt (1937) により詳細に砸究された。彼等は老人の側頭骨

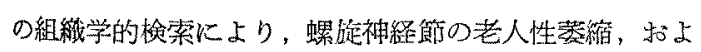

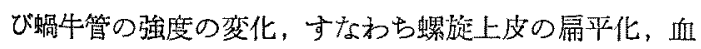
管带の血管の硝子化, 色素沈蕒, コルチ器の虚脱化, ラ イスネル膜の血管帯上皮への融箐等を述べている。

S. Rüedi (1951) は強大音䍩負荷に上り音響周波数に 一致したコルチ器の崩競，お上び，それに対応した血管 带の毛細血管の抬張を述へ，上皮細胞の代りに毛細血管

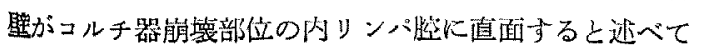

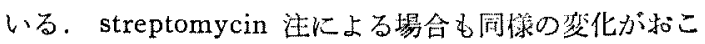
ると述べている。

M.B. Jorgensen (1962) は老人性難䏇の原因として Iffl管带の毛細血管壁の肥厚を述ぺている.

伎藤 (1957) は強大音響負荷がコルチ器の退行変性を

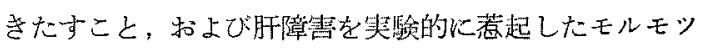
トは音響受傷性の高まることを述べた。

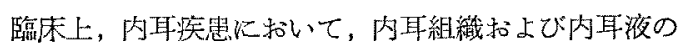

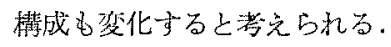

山川（1938）はメニエル氏病患者の剖検例に叔いて， 内耳のライスネル䐜の膨隆, 蕾脤を報告し, メニエル 氏病の病態生理の一面を明らかにした。.以来, 内耳の Hydrops と内耳液の分泌，吸収，またイオン構成との 関連性等が追求さ机ている。

炭酸脱水䤃素の組織化学的証明は倉田 (1953) に上り 始めて行われたが，その発色はかなり難しく，杰た不碓

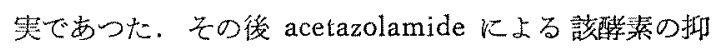
制試験孔可能となり，さらに1958 年 Häusler により free floating method を用いることにより発色が容易 に生じることが明かにざれた。

内耳血管带に炭酸脱水酥菜が存在することは Naftalin (1958) に上り想定され Erulkar 等 (1961) が猫 を用いて内耳組織，殊に血管带等化該醉素の存在するこ とを生化学的証明したと述べているが組織化学的証明は 報告されていない

\section{III． 実験方法および实験動物および成辕}

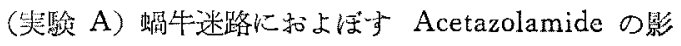
響について

1) 轶歌動物

笑駼動物にはプライエル耳取区射测定に便利なモルモ ットを用いた。实騟条件を同一にするため，体重 250 〜350gr の健康な動物を使用した。いつれる鼓膜に異常 なく、プライエル耳正反射正常なもので，20 秒10回枟 の回転徯腿振を測定し前庭機能に異常のないことを確め た。

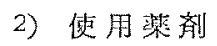

acetazolamide sodium (2-acetylamino-1, 3, 4,-thia diazole-5-sulfonamide sodium) "Lederle"

3) 春歌方法

acetazolamide sodium t $100 \mathrm{mg} / \mathrm{kg}$ の捚合でモル Eットに腹腔注を行い，1 時間後，3時間後，6時間後， 12 時間後, 24 時間後, Wittmaack 固定液を用いて山 川の方法に従い生体䧽流固定を行い，標本作成について 
あ山川記载の法により脱灰等行い,ッェロイデイン包埋 となし蝸牛迷路の modiolus に沿つて組織切片作成，切 片の厚さは䄪 $10 \mu$, Haematoxylin-Eosin 染色を得つた。

4) 罗螌成織

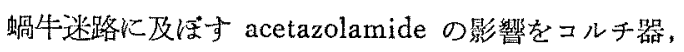
血管带, ライスネル膜, 基阍膜について観察した。

コルチ器および basilar membrane, limbus spiralis, sulcus spiralis int, 飞住正常モルモット群执よび acetazolamide 注射佯, 全時間, 全回昙に互つて罢常所見を 認めなかった（付図参炤）。

ライスネル膜の兴隆，伸展または攀維低下像に関して は対照正常群, acetazolamide 注射 1 时間, 3 時聞, 6 時間の場合もこれを認めず，12時閏後のむのに和いて

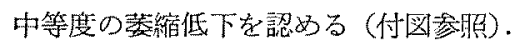

acetazolamide 投与により诸変が認められたのは血管 带においてであつて，血管带毛細血管の拉張像怙よび血 管带の尰脹で文る(付因参胉)。

これら所見は acetazolamide 投与 1 㭙間より12 時間 迄の各群において認められたが，1時間後に扎いて特に

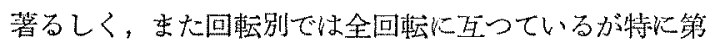
1〜2 回転に強く，3〜4 回転にはや小小さい应張像が認 るられ血管带の腫脹も少ない。

第1〜2回転では毛細血管の㹡張像が全血管带に互り， 単一毛細血管の内皮細胞が 1 側にて内リンパ空と直接接 し反対側が的管带下の結合織と接する程著るしい。

このよ5な拡張毛細血管の数は第 $〜 2$ 回転に和いては 5〜6認奶られ腫脹せる血管带の面䅡の殆えどを占める.

第2〜3回忶では执張毛紐血管の数は，2〜4k娍少可

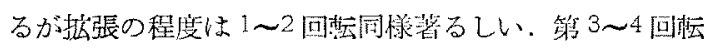
にも同樣 2〜40搥张毛細血管を学管带心認める.

時間的絓過では acetazolamide 投与後 1 㭙間の場合 に最もつよく，3時間，6時間の塄合もな和血管搪大は 强いが，12時間，24㭙间に抾掁像は少くなる。

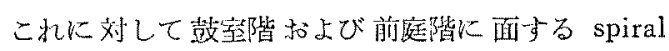

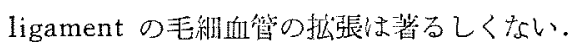

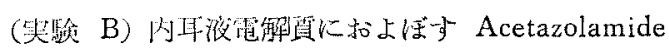
の影寶について

1) 实㖓動物实驗 $\mathrm{A}$ と同

2) 使用薬斉実歌 $A$ と同 $L$

3) 卧騟方法

奏跧 A に往い acetazolamide $100 \mathrm{mg} / \mathrm{kg}$ をモルモ ソト腹腔注老行い、注射後 1 時間，24 時間以内耳液採 取, その電荦質の $\mathrm{Na}$ 括よび $\mathrm{K}$ を測定. 非注射群と対
照比較した。

採取部位はC.A. Smith および島本・菊地の方法に従 い, 外リンバ液は正四空を介し鼓宝階より内リンバ夜は 卵形翣より採取した，芦原は基底膜を介して螖牛内リン パ液を採取しているが採取方法にかなり熹練を要するの でこれは行はなかつた。

採取方法はモルモットをェーテル麻酰後, 直らに断顽 Bullaをとり出し，搥大ルーベ下にて正円谷附近の血液

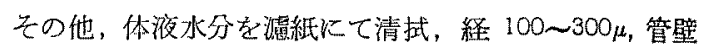
5 20 $\mu$ の硬質ガラス毛細管にて先つ正円空を軽く第刺， 毛紐管現象により外リンパ液を採取する，血液成分の混 入が氬われるるのはこれを放乘した。

次に鐙骨附近を濾紙にて清拭後，鐙骨を取り，外リン

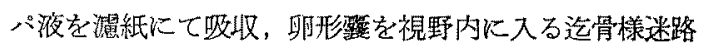
の一部を破琼，メラニン色素を有する卵形整の膨隆を確 認しこれを傷つけ以上らに注意しながら周囲の外リンパ

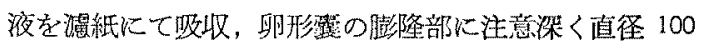

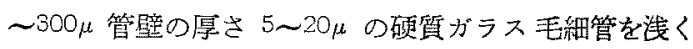
茅刺, 内リンパ液を採取する。

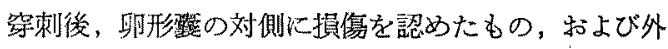
リンパ夜の侵入が考光られるむの，すなわち，内リンパ 液としては多量に採取さ机たすのはこれを放裹した。

上記採取内外リンパ液は，その硬筫ガラス毛細管の両 端をバラフインにて封入，番号記載後，冷室に保存し た。

微量容積は匊地の 報告する島津 SR-2 型座標測定器 にて直淮, 管壁, 辰さを計測, 岛本の力法に基つきが

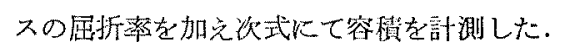

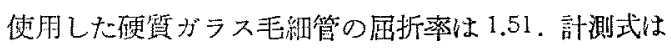

$$
\begin{aligned}
& \mathrm{R}=\mathrm{R}^{\prime} \frac{1}{\sqrt{1-\mathrm{R}^{\prime 2} / \mathrm{D}^{2}}} \fallingdotseq \mathrm{R}^{\prime}\left(1+1 / 2 \mathrm{R}^{\prime 2} / \mathrm{D}^{2}\right) \ldots \ldots \text { (1) } \\
& \mathrm{L}=\mathrm{L}^{\prime} \sqrt{\frac{\mathrm{a}^{2}+\mathrm{h}^{2}}{\mathrm{~h}^{2}}}=\mathrm{L}^{\prime}\left(1+1 / 2 \mathrm{a}^{2} / \mathrm{h}^{2}\right) \ldots \ldots \ldots \ldots(\mathrm{B}) \\
& \mathrm{r}=\frac{\mathrm{L}}{\mathrm{n}} \sqrt{1+\frac{(\mathrm{L}-\mathrm{r})^{2}}{\left(\mathrm{R}^{2}-\mathrm{L}^{2}\right)}} \ldots \ldots \ldots \ldots \ldots \ldots \ldots \ldots \ldots \text { (3) }
\end{aligned}
$$

$\mathrm{R}^{\prime}, \mathrm{L}^{\prime}$ は㩆微鏡下の毛細管の輝綵間距猚の $1 / 2$

R, L は通の毛細管の外経, 内経の 1/2

$\mathbf{r}$ : 直の毛細管の半経

$\mathrm{h}$ : 対物レンズと毛細管距猚

$\mathrm{b}$ : 座標测定器の nodal point と対物レンズ間距離 $\mathrm{D}=\mathrm{h}+\mathrm{b}$

なお，計測に際して xanthochrome を呈したものは 血液成分の混入したすのとして放菓した。 
针測容棈は外リンパ渡にて最小 $3.46 \times 10^{-4} \mathrm{cc}$ 最大 $3.49 \times 10^{-3} \mathrm{cc}$ 内リンパ液にては最小 $1.75 \times 10^{-4} \mathrm{cc}$ 最大 $2.32 \times 10^{-3} \mathrm{cc}$

次いで $5 \mathrm{cc}$ 容硬質試験管に減菌再蒸淘水を取り，試 作スポイドにて封入ガラス毛細管内の試料を注入，その 後，同ガラス毛細管内壁をスポイト利用により10回洗 滌，冷室に保存. Na., k の計測には C.A. Smith は造 心沈澱法を用小，菊地，島本は日立 EPV-2 焰光分光光 度計を推賞し，三宅，芦原は Perkin-Elmer C-52 型焰 光分光光度計の改良型を用いている，著者が今回使用し たのは島津 $\mathrm{R}-50$ 焰光分光光度計で $\mathrm{Na}$ は $\lambda=585 \mathrm{~m} \mu$, $\mathrm{K}$ は $\lambda=768 \mathrm{~m} \mu$ はにて計測した。

4) 実伢成績

正常モルモットの内リンパ，外リンパ容積および電解 質 $\mathrm{Na}, \mathrm{K}$ の各值は第 1 表, 第 2 表に示した。容磕は内り ンパに拈いては量少 $1.75 \times 10^{-4} \mathrm{cc}$ 上り最大 $2.32 \times 10^{-3}$ cc，外リンパに拈いては最小 $3.46 \times 10^{-4} \mathrm{cc}$ 上り最大 3.49 $\times 10^{-3} \mathrm{cc}$ 採取し得た。

採取量は C.A. Smith は Utricular Endolymph で

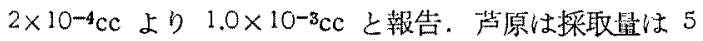

$\times 10^{-3} \mathrm{cc}$ 以下であるとし，骠準測量毛組管を作成して 試料を集琟し計测し，菊地は内リンバ液にて最少 $1.68 \times$ $10^{-4} \mathrm{cc}$ 最大 $1.08 \times 10^{-3} \mathrm{cc}$ 採取し得たと報告している.

各種動物の正常，内リンパ，外リンパ夜の䉓解筫 $\mathrm{Na}$ ，

K の值は各種報告者により多少異つている。

第】表拉よび第 2 表に正常モルモットより得た試料の 外リンパ，内リンパ $\mathrm{Na}, \mathrm{K}$ の湘定值を示す

外りンハの $\mathrm{Na}$ は最少 $76.1 \mathrm{meq} / 1$ 最大 $394.0 \mathrm{meq} / 1$ で 38 試料の平均值は $163 \pm 25.4 \mathrm{meq} / 1$.

$\mathrm{K}$ 以最少 $4.2 \mathrm{meq} / 1$ ，最大 $67.3 \mathrm{meq} / 1,38$ 試料の平均 䛧は $18.8 \pm 4.0 \mathrm{meq} / 1$ であつた.

内リンバは $\mathrm{Na}$ は最少 $6.4 \mathrm{meq} / 1$, 鼠大で $37.6 \mathrm{meq} / \mathrm{l}$ 34 試料の至均值は $16.2 \pm 3.4 \mathrm{meq} / 1$.

$\mathrm{K}$ は最少 $61.2 \mathrm{meq} / 1$, 最大 $320.2 \mathrm{meq} / 1$, 平均值は $135.4 \pm 32.8 \mathrm{meq} / 1$ であつた。

第 1 表，第 2 表に示す如〈内リンパ，外リンパ $\mathrm{Na}$ ， $\mathrm{K}$ 共乞の值は極めて広く分布している．それを正規分 布をしていると仮定して5\%の集却限界老示したのが平 均値に附した值である。このよらな広筙囲の異つた值が 得られたことは污染は極めて避けた積りであつたが採取

第 1 表 正常モルモツト外リンパ波電解貿

\begin{tabular}{|c|c|c|c|c|c|c|c|}
\hline 試 料 & Volume cc & $\mathrm{Na} / \mathrm{meq} / \mathrm{l})$ & $\mathrm{K}(\mathrm{meq} / \mathrm{l})$ & 試 料 & Volume cc & $\mathrm{Na}$ (meq/1) & $\mathrm{K}$ (meq/1) \\
\hline No. 1 & $1.97 \times 10^{-3}$ & 284.2 & 21.5 & No. 20 & $3.58 \times 10^{-4}$ & 76.1 & 11.9 \\
\hline No. 2 & $6.99 \times 10^{-4}$ & 203.8 & 48.6 & No. 21 & $1.26 \times 10^{-3}$ & 131.2 & 13.3 \\
\hline No. 3 & $5.02 \times 10^{-4}$ & 274.1 & 67.3 & No. 22 & $2.53 \times 10^{-3}$ & 120.4 & 8.6 \\
\hline No. 4 & $5.46 \times 10^{-4}$ & 315.7 & 40.1 & No. 23 & $2.59 \times 10^{-3}$ & 96.8 & 7.9 \\
\hline No. 5 & $1.01 \times 10^{-3}$ & 166.0 & 13.3 & No. 24 & $2.75 \times 10^{-3}$ & 110.0 & 9.1 \\
\hline No. 6 & $6.35 \times 10^{-4}$ & 156.0 & 22.8 & No. 25 & $1.29 \times 10^{-3}$ & 122.4 & 19.1 \\
\hline No. 7 & $7.12 \times 10^{-4}$ & 109.0 & 33.0 & No. 26 & $3.49 \times 10^{-3}$ & 86.9 & 6.8 \\
\hline No. 8 & $5.96 \times 10^{-4}$ & 147.0 & 17.2 & No. 27 & $9.42 \times 10^{-4}$ & 272.3 & 19.1 \\
\hline No. 9 & $5.35 \times 10^{-4}$ & 210.0 & 4.2 & No. 28 & $1.08 \times 10^{-8}$ & 394.0 & 20.7 \\
\hline No. 10 & $1.55 \times 10^{-4}$ & 161.0 & 21,3 & No. 29 & $1.12 \times 10^{-3}$ & 107.1 & 12.3 \\
\hline No. 11 & $9.19 \times 10^{-4}$ & 128.0 & 19.0 & No. 30 & $2.65 \times 10^{-3}$ & 95,3 & 9.4 \\
\hline No. 12 & $1.63 \times 10^{-4}$ & 190.0 & 23.9 & No. 31 & $1.72 \times 10^{-3}$ & 97.4 & 11.9 \\
\hline No. 13 & $1.29 \times 10^{-3}$ & 247.5 & 39.8 & No. 32 & $1.23 \times 10^{-3}$ & 118.7 & 14.0 \\
\hline No. 14 & $3.35 \times 10^{-3}$ & 127.0 & 13.4 & No. 33 & $1.42 \times 10^{-3}$ & 176.1 & 13.9 \\
\hline No. 15 & $7.88 \times 10^{-4}$ & 283.0 & 31.1 & No. 34 & $1.36 \times 10^{-3}$ & 137.9 & 12.4 \\
\hline No. 16 & $1.21 \times 10^{-3}$ & 159.0 & 18.6 & No. 35 & $6.57 \times 10^{-4}$ & 251,1 & 23.9 \\
\hline No. 17 & $2.62 \times 10^{-3}$ & 114.5 & 14.7 & No. 36 & $1.68 \times 10^{-8}$ & 136.3 & 12.6 \\
\hline No. 18 & $3.46 \times 10^{-4}$ & 101.8 & 10,0 & No. 37 & $2.14 \times 10^{-3}$ & 107.0 & 9.2 \\
\hline No. 19 & $2.21 \times 10^{-3}$ & 89.2 & 10.5 & No. 38 & $2.65 \times 10^{-8}$ & 94.9 & 7.3 \\
\hline
\end{tabular}

平均 $\mathrm{Na}: 163 \pm 25.4 \mathrm{~K}: 18.8 \pm 4.0$ 
第 2 表 正常モルモット内リンパ没電解貿

\begin{tabular}{|c|c|c|c|c|c|c|c|}
\hline 試 料 & Volume ce & $\mathrm{Na}$ meq/l) & $\mathrm{K}(\mathrm{meq} / \mathrm{l})$ & 武 料 & Volume cc & $\mathrm{Na}$.meq/1) & $\mathrm{K}(\mathrm{meq} / \mathrm{l})$ \\
\hline No. 1 & $1.24 \times 10^{-\mathbf{3}}$ & 13.1 & 127.2 & No. 18 & $7.49 \times 10^{-4}$ & 6.8 & 287.0 \\
\hline No. 2 & $9.40 \times 10^{-4}$ & 9.7 & 61.2 & No. 19 & $2.17 \times 10^{-4}$ & 37.6 & 161.0 \\
\hline No. 3 & $7.50 \times 10^{-4}$ & 10.0 & 66.7 & No. 20 & $3.97 \times 10^{-4}$ & 21.4 & 122.0 \\
\hline No. 4 & $1.55 \times 10^{-3}$ & 16.9 & 78.8 & No. 21 & $8.37 \times 10^{-4}$ & 22.7 & 316.6 \\
\hline No. 5 & $8.25 \times 10^{-4}$ & 15.6 & 70.9 & No. 22 & $1.47 \times 10^{-3}$ & 15,0 & 207.5 \\
\hline No. 6 & $8.20 \times 10^{-4}$ & 11.0 & 108.0 & No. 23 & $3.76 \times 10^{-4}$ & 12.3 & 106.4 \\
\hline No. 7 & $7.06 \times 10^{-4}$ & 11.5 & 120.3 & No. 24 & $1.18 \times 10^{-3}$ & 26.7 & 161.0 \\
\hline No. 8 & $2.32 \times 10^{-3}$ & 12.9 & 84.4 & No. 25 & $1.09 \times 10^{-3}$ & 25.0 & 256.9 \\
\hline No. 9 & $1.18 \times 10^{-3}$ & 18.3 & 80.0 & No. 26 & $6.71 \times 10^{-4}$ & 13.5 & 158.0 \\
\hline No. 10 & $5.52 \times 10^{-4}$ & 13.2 & 82.1 & No. 27 & $7.36 \times 10^{-4}$ & 11.3 & 112.0 \\
\hline No. 11 & $1.19 \times 10^{-8}$ & 7.4 & 87.6 & No. 28 & $6.94 \times 10^{-4}$ & 26.0 & 70.0 \\
\hline No. 12 & $1.03 \times 10^{-3}$ & 6.6 & 65.4 & No. 29 & $8.62 \times 10^{-4}$ & 9.6 & 104.4 \\
\hline No. 13 & $9.99 \times 10^{-4}$ & 8.3 & 97.6 & No. 30 & $4.33 \times 10^{-4}$ & 16.5 & 132.8 \\
\hline No, 14 & $9.21 \times 10^{-4}$ & 11.8 & 79.8 & No. 31 & $8.49 \times 10^{-4}$ & 22.1 & 123.7 \\
\hline No. 15 & $2.05 \times 10^{-3}$ & 8.8 & 79.7 & No. 32 & $9.77 \times 10^{-9}$ & 6.4 & 87.0 \\
\hline No. 16 & $5.47 \times 10^{-4}$ & 36.6 & 210.0 & No. 33 & $7.14 \times 10^{-4}$ & 12.4 & 67.2 \\
\hline No. 17 & $3.77 \times 10^{-4}$ & 16.3 & 1120 & No. 34 & $5.08 \times 10^{-4}$ & 31.1 & 320.2 \\
\hline
\end{tabular}

平均 $\mathrm{Na}: 16.2 \pm 3.4 \mathrm{~K}: 135.4 \pm 32.8$

試料に血液成分その他の混入を来したか，採取試料の一 部分を操作上消失したか，东た計測に当つて採取試料各 容積の差のため，同一標準曲線上に括いて計測できなか つた事等が関与していると考克られる。

計測值が分散することは Smith，芦原等の報告にもみ られ，特に Erulkar u Maren 等に批いて著るしく，こ のよらな微量試料の推計学的処理の困難を示していると 考える.

Acetazolamide 投与 1 時閪比顿いて, 外リンパの $\mathrm{Na}$

第 3 表 Acetazolamide 投与 1 㭙間後 外リンパ液電解質

\begin{tabular}{l|c|c|c}
\hline & Volume cc & $\mathrm{Na}$ (meq/1) & $\mathrm{K}(\mathrm{meq} / \mathrm{l})$ \\
\hline No. 39 & $1.54 \times 10^{-3}$ & 118.5 & 11.0 \\
No. 40 & $1.23 \times 10^{-3}$ & 117.9 & 11.2 \\
No. 41 & $1.49 \times 10^{-3}$ & 107.4 & 13.4 \\
No. 42 & $8.13 \times 10^{-4}$ & 153.7 & 18.4 \\
No. 43 & $1.02 \times 10^{-3}$ & 154.7 & 15.7 \\
No.133 & $1.88 \times 10^{-3}$ & 100.5 & 14.1 \\
No.138 & $1.40 \times 10^{-3}$ & 119.0 & 15.0 \\
\hline & & $124.5 \pm 19.3$ & $14.1 \pm 2.3$
\end{tabular}

値は樶少 $100.5 \mathrm{meq} / 1$, 最大 $154.7 \mathrm{meq} / 1$ 全例 7 の平均 値位 $124.5 \pm 19.3 \mathrm{meq} / 1$.

$\mathrm{K}$ 值保最少 $11.0 \mathrm{meq} / 1$, 最大 $18.4 \mathrm{meq} / 1$ で平均檤は $14.1 \pm 2.3 \mathrm{meq} / 1$ であつた (第3表).

一方内リンパ派は試料総数 $13, \mathrm{Na}$ 値は最少 $5.5 \mathrm{meq} / \mathrm{l}$ 最大 $15.6 \mathrm{meq} / 1, \mathrm{Na}$ の平均値は $9.25 \pm 2.0 \mathrm{meq} / \mathrm{l}$ であ つた. K は最少 $78.7 \mathrm{meq} / \mathrm{l}$, 最大 $169.8 \mathrm{meq} / \mathrm{l}$, 可均倠 は $123.5 \pm 17.6 \mathrm{meq} / 1$ であつた。

採取容䖽は最少 $1.75 \times 10^{-4} \mathrm{cc}$, 最大 $1.06 \times 10^{-3} \mathrm{cc}$ で 配つた(第 4 表).

注射後 24 時間の各值は, 外リンパにおいて $\mathrm{Na}$ は最 少 $111.8 \mathrm{meq} / 1$, 最大 $166.4 \mathrm{meq} / \mathrm{l}, \mathrm{Na}$ の平均值は 136.5 $\pm 18.5 \mathrm{meq} / 1$, K は最少 $13.3 \mathrm{meq} / \mathrm{l}$, 最大 $24.6 \mathrm{meq} / 1$, 平汮値は $19.6 \pm 3.6 \mathrm{meq} / \mathrm{l}$ であつた。採取容積は最少 $1,00 \times 10^{-3} \mathrm{cc}$ ，最大 $1.67 \times 10^{-3} \mathrm{cc}$ であつた(第 5 表).

内リンパに蛙いては $\mathrm{Na}$ は最少 $7.2 \mathrm{meq} / \mathrm{l}$, 最大 33.7 $\mathrm{meq} / \mathrm{l}$, 平均值 $12.8 \pm 7.3 \mathrm{meq} / \mathrm{l}$ であり，K は最少 105.8 $\mathrm{meq} / \mathrm{l}$ であり，最大 $144.3 \mathrm{meq} / \mathrm{l}$, 平均值は $129.5 \pm 12.6$ meq/1 であつた.

採取容積は最少 $5.23 \times 10^{-4} \mathrm{cc}$, 最大 $1.75 \times 10^{-3} \mathrm{cc}$ で あつた (第6表)、以上の結果を棒グラフで示したのが 第!図である。 


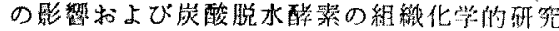

第 4 表 Acetazolamide 投与. 1 捗間後

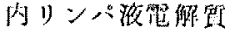

\begin{tabular}{l|c|c|c}
\hline 武量番号 & Volume cc & Na (meq/1) & K (meq/1) \\
\hline No. 36 & $3.04 \times 10^{-4}$ & 15.6 & 121.7 \\
No. 37 & $5.63 \times 10^{-4}$ & 8.7 & 94.3 \\
No. 38 & $8.18 \times 10^{-4}$ & 7.0 & 162.0 \\
No. 39 & $3.48 \times 10^{-4}$ & 11.5 & 100.0 \\
No. 40 & $5.38 \times 10^{-4}$ & 5.6 & 83.6 \\
No. 41 & $8.06 \times 10^{-4}$ & 9.0 & 158.2 \\
No. 42 & $8.26 \times 10^{-4}$ & 6.4 & 133.2 \\
No. 43 & $6.35 \times 10^{-4}$ & 5.5 & 78.7 \\
No. 44 & $1.75 \times 10^{-4}$ & 14.3 & 131.4 \\
No.140 & $6.12 \times 10^{-4}$ & 8.5 & 132.0 \\
No.141 & $9.71 \times 10^{-4}$ & 6.9 & 114.0 \\
No.142 & $4.25 \times 10^{-4}$ & 13.0 & 126.0 \\
No.143 & $1.06 \times 10^{-3}$ & 8.3 & 169.8 \\
\hline & & $9.25 \pm 2.0$ & $123.5 \pm 17.6$
\end{tabular}

第 1 図

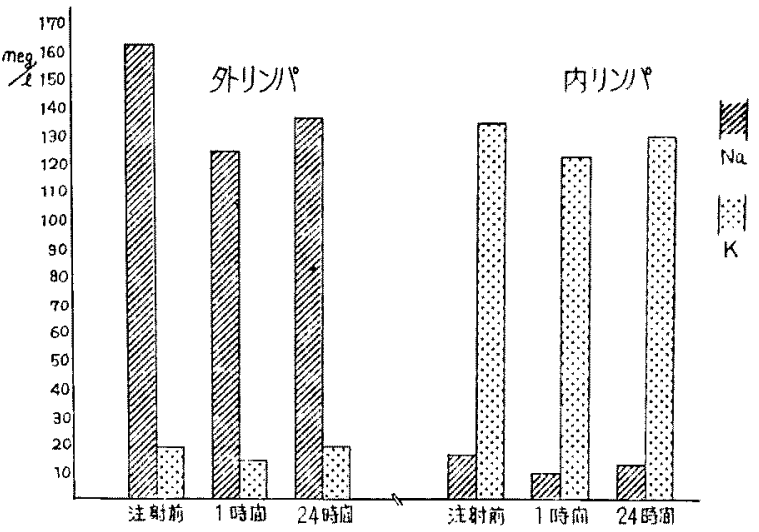

第 7 表

\section{METHOD FOR CARBONIC ANHYDRASE}

(Hausler, 1958: after Kurata)

(Cold microtome, fresh sections, post-fixed in cold acetone: free-floating)

Preparation of Incubating Medium

Solution A. To $1.0 \mathrm{ml}$. $0.1 \mathrm{M} \mathrm{CoSO} 4$ add $6.0 \mathrm{ml}$. $0.05 \mathrm{M}-\mathrm{H}_{2} \mathrm{SO}_{4}$ (This solution is stable).

Solution B. Dissolve $1.0 \mathrm{~g} \mathrm{NaHCO}$ in $50 \mathrm{ml}$. $0.1 \mathrm{M}-\mathrm{Na}_{2} \mathrm{SO}_{4}$ (Freshly prepared before use)

Before incubation pour solution $B$ into solution $A$ in order to avoid a momentary high concentration of cobalt ions.

Method

(1) Post-fix sections in cold absolute acetone ( 0 4) for 1 hour.

(2) Transfer directly into incubating medium at $18-20^{\circ}$. Incubate for $1 / 2$ to 2 hours It is important to keep the sections floating on the surface of the medium.

(3) Wash in distilled water for 2minutes.

(4) Transfer to dilute $\left(\mathrm{NH}_{4}\right)_{2} \mathrm{~S}$ solution for 1 minute.

(5) Wash in tap water.

(6) Mount in glycerine jelly.

Result

A positive result is indicated by black or brown deposits of cobalt sulphide control sections incubated in the presence of $4 \times 10^{-3} \mathrm{M}$-Diamox (sodium salt) should show no staining. 
(実験 C) 孷酸脱水酵素の組織化学:的研究

1) 実験動物

実験動物には成熟および必若ラッテ。有色成熟モル モット（体重約 250～350gr）拈よび人間の剔出督を用 いた。

2) 染色 法

ラッテおよびモルモツトの腎を剔出．これを直らに 凍結, 厚さ $20 \mu$ の新鮮凍結切片を作つた. 次いで, 室温 $\left(20^{\circ} \mathrm{C}\right.$ ) にて約 10 分間放置, Häusler 原法 (第 7 表）に従い, 冷アセトン固定, 1 時間後 $18 \sim 20^{\circ} \mathrm{C}$ に て 1 時間半, incubate し, 水洗後, 黄色硫化アンモン にて発色させた.この際 incubation はfree floating で行うことが Häusler により考案された．この点が 彷来の食田法と異なる大きな点である。

次いで人間の剔出腎についても同様染色を試みた，更 にこの染色法を内耳に応用するためあらかじめスライド グラスに 2〜3\% の薄いコロジウム膜を作つて置き，そ の上に湅結切片を載せ，基質液を注射器でュロジウム膜 とスライドグラスの間に注入 (第 2 図) 表面張力を利用 して発色を容易ならしめると同時に，骨部と空鿣と軟部 よりなる内耳組織の崩壊を可及的に防いた。この場合， 固定液としてアルコール (70〜80\%) を用いた.

抑制实験は acetazolamide sodium $4 \times 10^{-3} \mathrm{~mol}$ 附加 基質液を用いた。

なお，内耳切片の作成に拈いては，モルモツトを断 第 2 図

スライド・グラス

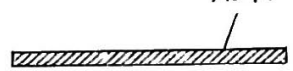

2

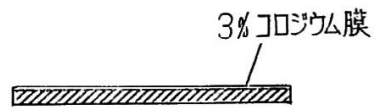

3

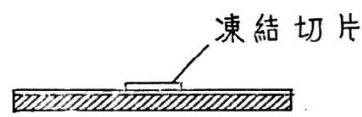

4

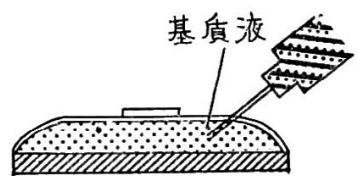

第 3 図

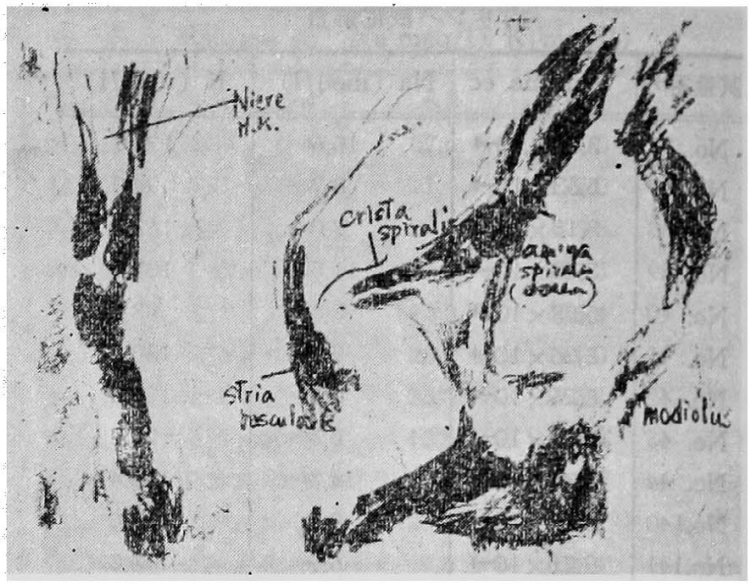

頭滨血後 Bulla を開け，骨様蝸牛迷路の第 3〜4 回転の 骨壁を拡大ルーペ下にて 針にて 結合織と分離, 剥離し た後、これを modiolus と共に腎組織に包埋後凍結, modiolus 軸に平行に切つた。この際得られる形態の略 図を第 3 図に示す

3）奏騟成縝

コロジゥム膜上で反応を行つた Häusler 变法に扎い てもラッテ腎においては Häusler の記载する如く近位 尿細管に活性強く糸球体扎よび䯣質には活性は認められ なかつた（付図参照）.

モルモットにおいても同様な結果が得られた，人間の 剔出腎においても活性を認め，動物による発色に差は認 めなかつた．人剔出腎の活性部位は強抎大にて近位尿細 管上皮細胞の遊離渌，与なわち brush border そ一致 するようにひたをなして認められた（付図参照）.

以上コロジウム漠上に切片を置き, アセトンの代りに アルコールを用い固定した後，コロジウム獏下に基質液 を入れた Häusler 変法に拈いても活性には变化は認め られなからた．内耳組織の非脱灰切片の作成は難しい問 題であり，切片を薄くすれば形態がかなりくずれる. 著 者は $20 \mu$ の切片により反応を行つたが modiolus の骨 組織である Lamina spiralis ossea 等のため, 膜様蝸 牛の正しい位置関係は得られなかつたが，付図に示す如 く Häusler 変法で染色した場合と, その acetazolam. ide $4 \times 10^{-3} \mathrm{~mol}$ 附加基質液で抑制した場合と比較すれ ば Lamina spiralis ossea につざく Crista spiralis の 透明部より先に 屈曲して 血管帯が存在するのが 認めら れ，血管帯と周囲㹂組織尿細管とは同様の炭酸脱水酵素 活性を有し, acetazolamide で扣制した場合は両者とす 
発色せず，血管带に一致してメラニンの黒褐色顆糔を認 める.

\section{IV. 䓔按}

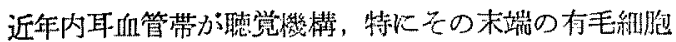

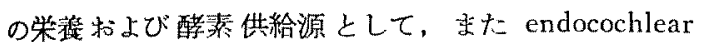

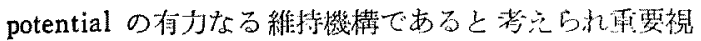
されて来た。

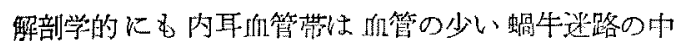

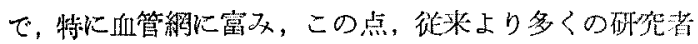

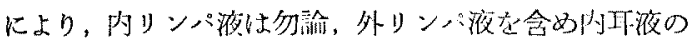
分泌部位上考えられてきた。

Seymour (1954) 值管带の毛細血管絧に括ける偱環 の速度は spiral ligament お゙よびその他の部位におけ る毛細血管組の速度上り遅いと述へ，Smith (1957) は

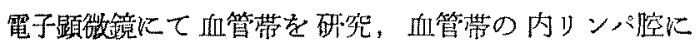
面する方より marginal cell, lighter cell, basal cell layer 亡区分し marginal cell は多くの膜㥞精造を含 み，特比 Pease の報告する infolded basal plasma membrane の存在を報告した。また毛細衈管絧はこの 部心存在し marginal cells や他の細胞の薄い cytoplasmic content によつて四まれると述べている.

血管带の病的惭見に関しても種々報告があり S. Rüedi

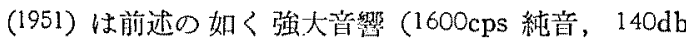
64 㭙間)を負渮した場合，モルモット内耳の音響周波数

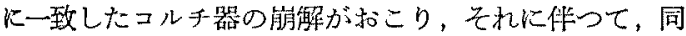
しその対応血管带の毛細䘏管の拡張，そして上皮細胞の

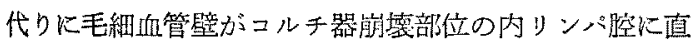
面すると報告，さらに streptomycin の注射によりコル 千器の崩器をきたした場合にも，同部の血管帶に上皮の

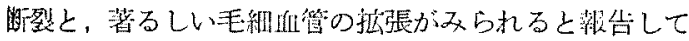
いる。同様なことは quinineによるコルチ器の崩慗部 の租管带に求いても認めら扎る。砣素毒に和いては上皮

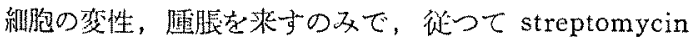
や quinine の場合の血管带の変性は主として circulatory system に影響与ると考えている。

M.B. Jorgensen (1962) は老人性蜼腮の 原因として 血管带毛細血管壁の变化を Haematoxylin-Eosin 染色 扣上び PAS 染色で研究，その肥厚像が著るしいと酦告 している. Seymoux (1954) 忹全身の sclerotic 㦄变化

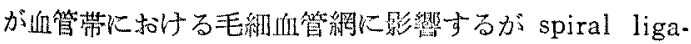
ment や内耳の他の部位には影綪しないと述べた。

山4川 (1938), Hallpike-Cairns (1938), Wolff (1938) 等がメニエル氏病の剖検例を報告, ライスネル膜の伸届

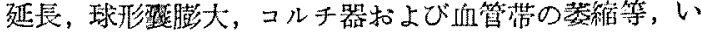
つれも内りンパ水嗹の所見を述へ，メ二エル氏病の病態 の一因が内耳の Hydrops によることを明らかにした。

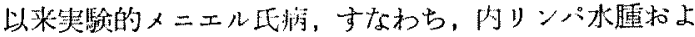

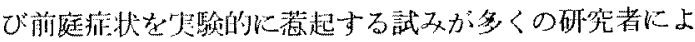
り行われ，Skoog (1939) はフオルスマン挩体をモルモ

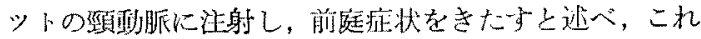

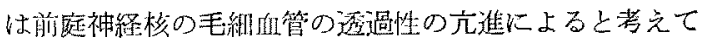
いる.

内藤 (1950)はピロカルピン, アセチルコリンを内耳

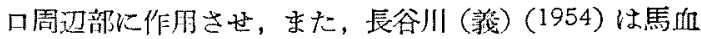

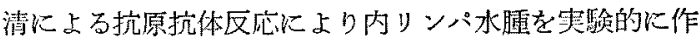
ることに成功したと郝告している。生体に Hydrops が おこる場合 Wullstein の述べる如く霞解質の状態と， その調節買常が原因となされることが多い。

内リンパ水蕾の際，内耳液がいかに变動与るか不明

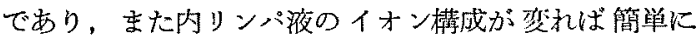
Hydrops その他組織学的觉化が薏起されるかどらか子 末解決である。また内リンパ水腫はメ二エル氏病の発作 之直接関係があるか，どらか不明の点も少くない，

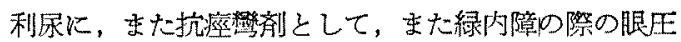
上昇の治療削として広く用いられている acetazolamide が内耳組穖怙よび内耳夜にいかに作用するかは，上記各 種の点より，與味あるところである．著者の得た成績は 前述の如くで acetazolamide sodium $100 \mathrm{mg} / \mathrm{kg}$ 腹腔 注後 1 㭙問上り6時䦌治の例にて，螖牛迷路の中て，血 管帯の毛細血管侼に著るしい变化を認めた：ライスネル 膜の脯㦀，腫脹，ぬたは，萎縮低下等，内リンパ水尰，

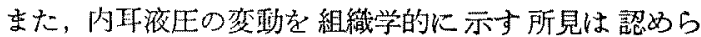
扎なかつた。 また Smith (1957) Borgensen (1957) 等 により队リンハ分速が行は机ていると考えられている

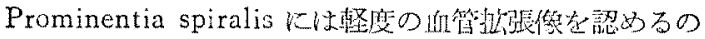
みであつた。この点，血管带はその同因細織と異つた反

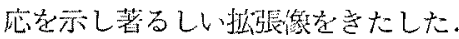

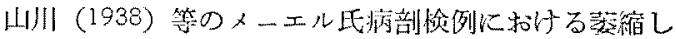

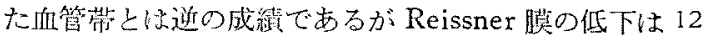

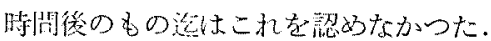

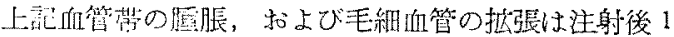

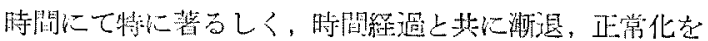
可しているが6時间，12時间迄琶めることがでさる。

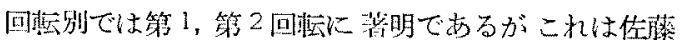

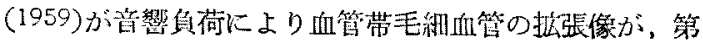




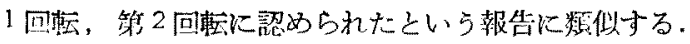

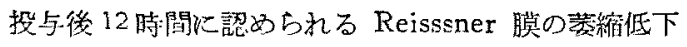
は内リンパ正の低下傾向を示すものと考兵られる。投与 せる acetazolamide sodium は sulfonamideではある が bacteriostatic な sulfonamide とは化学構造す異な り non-bacteriostatic であり，著るしい利疗效果を有 している.これは sulfonamide の酥素抑制効果，特に

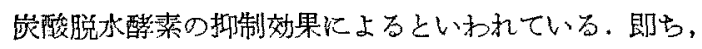
次式

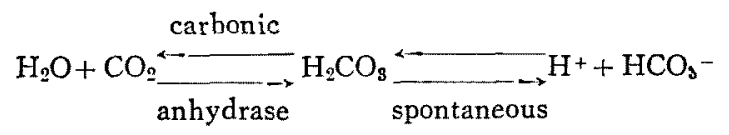

の反応を抑制することにより $\mathrm{HCO}_{\mathbf{s}}-$ の督上りの消失， および $\mathrm{Na}, \mathrm{K}, \mathrm{H}_{2} \mathrm{O}$ の運搬をする。従つて尿のアルカ リ化が括こる。この acetazolamide sodium の体液無機 イオンに及ぼす影響については T.H. Maren (1954) の 詳細な報告がある，彼等の実験(実験動物は大をたは猫) では血清中のナトリウム, カリウム值の減少，尿中のナ トリウム，カリウム，炭酸各イオンの增加，フンモニア イオンの減少を報告している。

Acetazolamide は心蔵疾患に推々る利尿作用の目的 の他 epilepsy に乱いて抗痤れん作用により，むた緑内 障の時の眼王降下作用により，監床上よく用いられてい る.しかしながら，その作用機序に関しては全て明確に

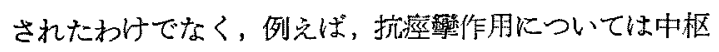
神経系の炭酸脱水醭素の抑制儿上るという說, 和上び, それによつて生じる slight acidosisによるという説も 唱えられている。

Woodburry (1958)によれば acetazolamide 投与に

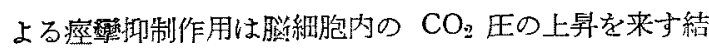
果であると報告している，彼によ机ば，細施は $\mathrm{CO}_{2}$ の 調節器であり $\mathrm{CO}_{2}$ の增大が紐胞の代謝よりくると述べ ている. 従つて炭酸脱水降素の抑制紐胞内で代謝的に 作られた $\mathrm{CO}_{2}$ が細胞上り遊燋する割会を抑制すると推 定している，この事は $\mathrm{CO}_{2}$ が細胞内で炭酸として生垍 され，細胞膜が炭酸に対して透過性が中等度であれば拉 こるだるらと述べている。

Shanes (1948) の拣験で細胞を離れる $\mathrm{CO}_{2}$ の殆儿

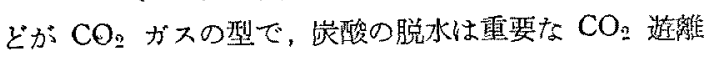
の反応調律因子であると考觉ている。

従つて炭酸脱水醉素抑制，および $\mathrm{CO}_{2}$ ガス投与によ

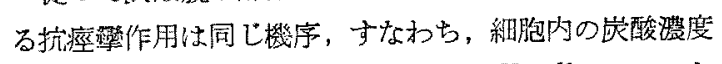
の急速な上韭に上ると説明している，Woodburry はま だacetazolamide 投与により脳紐胞内の $\mathrm{Na} / \mathrm{K}$ 比が低 下すると述へている。緑内障治療剂としての acetazolamide sodium の作用は毛様体に打ける $\mathrm{HCO}_{3}$ - 分证 譏能低下に基つくと考光られている。これは Myotics の流出增大とは異つた上記の機序で眼压低下をきたすと 考壳られている。

$s=エ ル$ 氏病の治療には外科的療法と内科的療法とに 大別される.外科的療法は久ニエル氏病を内耳水腫と考 点これに其つくく Portmann 氏手術，括よび，その川川， 内藤变法がある。

内科的療法としては，メニエル氏病を内耳血行障得に 本態ありとしての，7\%重曹水静注. ニコチン酸了ミ

ド，カリクレイン，その他，高張液投与等がある。一 方，内耳水蕾を除く目的での acetazolamdie 投与試 みられている、いつれにしてる緑内障に乱ける眼王測定 の如く，内リンパ压の測定が不可能であり，メニエル氏 病発作時の本態は不明であり，内藤等の分離する如く， アレルギー，focal infection，内分泌異常等，種々の因 子に上る内耳血行障害，拈上びその結果としての内耳水 陲が有力視されている.

acetazolamide 投与により血管带の毛細血管の摭大像 がみられたこと，また，その時閒的経過および，その回 転別に善の認奶られたことは (1) acetzalamide 投与に 上る，体液のナトリウム，カリウムの減少に上る，内 耳血管の血流の蝺解質組成の変化に基つくのか, (2) た Naftalin の述べる如く，血管带括よび，その他， 膜棁迷路の何儿らかの盼所に嵌酸脱水醉素が存在し， その抑制により Woodburry の竍告するように岸酸が 不理の增加が，血管带そのものに，あるいは，内りン 焲に生し，その影響が血管带毛細血管に及んだか（3) また血管带括よび，その他の迷路組織の炭酸脱水醉糸 抑制に上り内リンパ，外リンパ夜の特異なるイオン满 成に影響し，矢の結果として生したものか (9)大量の acetazolamide 投与により血管带そのもの〉物資代謝に

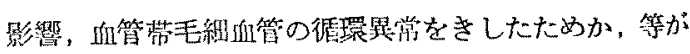
考光られる。しかしながら生体固定に斿ける血管拨張 と生理的な搥涱との関連性について追求すべき問題が あるが，佐藤 (1957) (1959)，Rüedi (1945), H. Davis

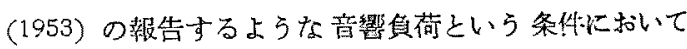
コルチ器の障管もきたし易い基碟回転汇近く，毛細血管

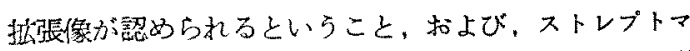
イシン。キニン等の聴器毒投与により生じるコルチ器崩

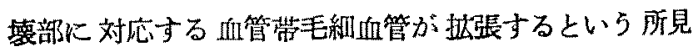




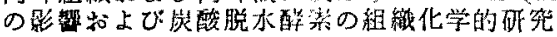

は、いずれも止体固定により得られた所見であり，藷者 が今回得た acetazolamide 投与による所見も，これら

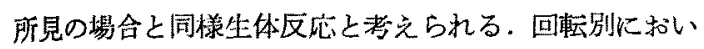

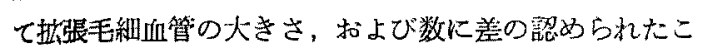

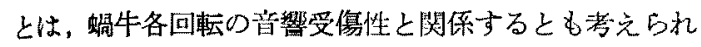
万。

Bekesy 等の報告与る如く，塥牛有毛細胞の周波数特 舆性，高者加基礎回転より少し上の部より始まり，漸炏

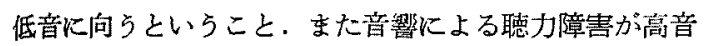
に多いといら事拣，またSM 中毒による末梢迷路陵害 も基碟回転に強いといら哥実. キニーネ，CO 中毒等に 上る内耳障害す高音部が犯されるといらこと，さらに河 本 (1962)，中井 (1962) 等も回転別に打壮る血管帯酸 素消费量の差を述べている等，数多くの点より考葴すれ ば acetazolamide 投与に上り，第 $1 \sim 2$ 回転部位の毛細 血管の掋大像か特に著るしいといらことは，この部回転 の特異性を示すと考光られる。 また Seymour (1954) の述べよらな血流の停滞現象を示するのとる考光られ

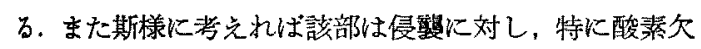
そをきたし易い部位であるか死しれない，以上の点より 血管帯子，それ《対応する有毛細胞同様，回転别に特異 性を有しているのではないかと推察される。

Acetazolamide の内耳液に刘する影響に䕡しては内 リンパ，外リンパ液とも，その採取量の僅少，末よび， その解剖学的棈造上り生じる測定值の広沉な分有のため 推訢学的に有甞の值をらること怯, かなりの技術上例数 の集積を要する，著者は内・外リンパ液のナトリウム， カリウムの低下傾问安諗めたが推部学的に有意と判定す

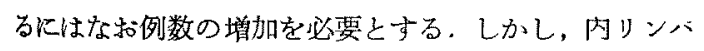
のナトリウムの低下は顕著であり，現在の例数に祘い て，5\%の危険率で有意であつた。

内・外リンパ液電解質に対する独風の影響に関して K，本邦にて芦原 (1960)，菊地（1957）の報合がある. 菊地はピロカルピン、フドレナリン、アトロピン，７ \%重曹水注射群について報告して呫り，ピロカルピン注 射により，内リンパのカリウム値の增加を，アドレナリ ンルアトロピン注射群にては变化を認めずと報告．また 7\%重曹水注射により, 内リンハ液のカリウム值の低下 をきたしたと述べている。

岛本，菊地（1956）はメニエル氏病叔よび，それに関 連せる一群の内耳矤患の原因について，内リンハ・・カリ ウム維持機転の障害に本態むりと考えている。

芦原 (1960) はコーチソン拉よびストマイ投与時の影

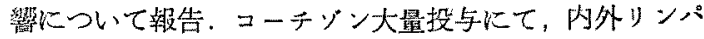
液共, ナトリウム值の壦加，カリウム値は娍少する傾向 にあると報告，この場含，增加傎向は，内リンハより， 外リンパに拈いて，や上著明と述へている、芦原はこれ らの变化が対照血清の同様な变化より大であると啹告. ストマイにては队外リンパの，ナトリウム，カリウム值

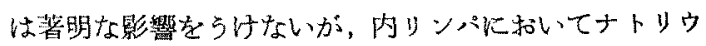
ムはや」低下，カリウムはプライエル区射低下と平行し て一般に增加の傾向を認めたと述べている。

acetazolamide の影響に関しては S.D. Erulkar u. T.H.Maren (1961) が報告. 猫を用いて $50 \mathrm{mg} / \mathrm{kg}$ 静注 後内リンパのカリムの減少を述べ，外リンパのカリウ ムは変化がないと述べている、彼等は，この成縝によ り，炭酸脱水酔素は内リンパのカリウムの active sekretion の機構に重要な役割をなし，恐らく，この液体 の過乘形成にも重要な彼割をなすと述べている。しかし ながら彼等の类跧に和いても計湘值は極めて広く分散し て括り，ての推計学的処理は行はれていないまた，彼 等は内リンパ液の $\mathrm{CO}_{2}$ の值は血清や睬䯚液と变らない 15〜21 mM/1 を示すと述べている. 彼等は猫の血清に 揖いて $\mathrm{CO}_{2}$ は投与前 $17 \mathrm{mM} / 1$, 投与後 $11 \mathrm{mM} / 1$ と述 ベている.

Wullstein (1961) は前述の如く, 人間のメニエル氏 病の電解質の計测を行い, 前庭階の外リンパ派のカリウ 么值の增加，末よび内リンパ液のカリウム値の軽度低下 およびナトリウム值の增加傎向を还べライスネル膜の選 択的透過の变化を考えている。

Woodburry は脳細胞に括ける Na/K 比が acetazolamide 投与に上り低下すること，すなわら，細胞内の ナトリウム值の低下が著るしいと苇告している。

内リンパ液は前述の如く細胞内液と同しく，低ナトリウ ム, 高カリウムであり, 外リンパ液は反対に細胞外液の

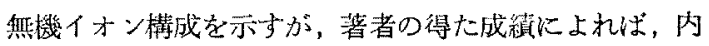
リンパ液は acetazolamide 投与により $\mathrm{Na} / \mathrm{K}$ 比は低下 し, Woodburry が䏼細胞で得た成績之類似する。この 事は両者の間の生理機構に関連のるる絬果によるとる落 充られる。

内外リンパに及ぼ acetazolamide の影整を考觉る とき，外リンバは血清と，その然機イオン構成が類似し ている故，外リンパのナトリウム，カリウムの堿少は血 清に由来していると考劣られる。

内リンパ液は細胞外液としての外リンパ液の中に膜様 構造にて国まれ存在し高カリウム，低ナトリゥムの特 
異なる細胞外液としての構成をむつがこのためには，膜 称構造はかなり強力な操択性透過性をるつが,ナトリウ ムの排泄機構を持たねばならぬ、acetazolamide 投与に より，内リンパのナトリウム值が減少する結果を得た が，この場合，膜称構造のナトりウム・ポンプのような メカニズムに何らかの影響があつた結果かどらか未解で ある、しかしながらこのよらな energy を要する機権は 血流が問題となる。

従つて血液供給の多い血管带がこれ红当ると栲党易 い. Vosteen (1958) 敊よび小出はモルモット血管带に コハク酸脱水素醭素，拈よびチトクローム・オキジダー ゼが多いと報告している。

著者の実験においてみられた acetazolamide 投与後 の著明な毛細血管の抾張像は，該薬绪に上り血管帯の化 学反応何らかの著るしい変化を来した結果と考学られ る. 更に内リンパ液のナトリウム・イオンが該薬剤によ り減少したといら事は Naftalin (1958) が推測し， た Erulkar (1961) が生化学的炕笑証したと報告するよ

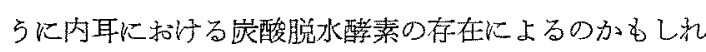
ない. 著者も組織化学的に Häusler 法变变, 内耳血 管带の炭酸脱水酵素の染色儿成功し，該酵素が血管带に あることを確認した。しかしながら該醉素が内耳液電解 質の転送にどのような特異性を発揮しているかは，な 拉，問題上なるところであり，今後の研究によらねばな らないと思はれる。

Merle Lawrence (1960) はライネル瞙を賣傷させる と，その部位の有毛細胞が直ちに破媴されると述へ，そ の際の内耳電気現象を損傷部位の上下の回転にて記録， 内リンパ液の流れに関して彼の見解を明らかにした。す なわち内リンパ液の流れが Guild の唱える如く，血管

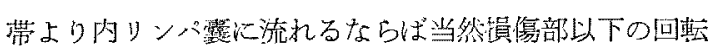
の電気現象の消失しなければならない之考え，彼は内り ンパが Naftalin 等つ唱克る外リンパり，ライスネル 獏を介して生じるという説を正しいとしている。彼浮 者を radial theory と名付け Guild の説を longitudinal theory と区別している。

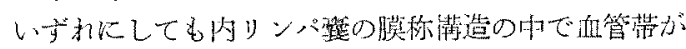
内リンパ液の生成に閣し重琹な役䈀を果している事は開

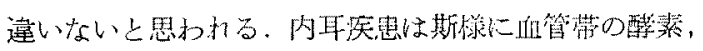
血液供給と関係がある上思はれれるが，舆谷川教授の唱べ る如く, 螺败器つ底面を走る螺旋血管 (Vas spirale) 之の関保も，密接之思はれる。

この力面の硎究は現在のところ，少く著者も今回の笑 験では知見を得ることはできなかつたが，今後、研究さ
れねばなら点と䠸える。

\section{IV. 結 語}

（1）内耳液の分泌，吸収拉よび循謤の機序の 1 端を 追求する目的で正常健康モルモットに acetazolamide sodium $100 \mathrm{mg} / \mathrm{kg}$ 腹腔注を行いこの際の内耳組織の変 化，および，内耳液電解犋の变化を観察した。

（2）コルチ器，ライスネル膜，基底膜，血管带等に特

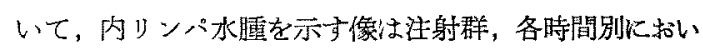
て，これを認めなからた１2時間後において，ライス ネル膜の低下像家認めるものがあつた。

(3) 注射後に扎ける最も著るしい所見は，血管带毛細

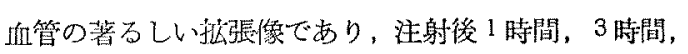
6 時間に認奶られ，特に1時間後に和いて著明であり， 回転別ては高暑感受部と知られている基碟回転に近く䔄

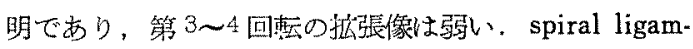
ent 和よび他の螎牛組織の血管像の変化は少い。

（4）内耳液電解質は，その量的な問題より分布はかな り大で亦るが，注射後 1 時間にて内外リンハ液共,ナト リウム,カリウムの減少傾向を認め, 特に内リンパのナ トリウムの減少は $5 \%$ の传険率で有意であつた。

(5) 炭酸脱水醏素の組織化学的証明法である Häusler

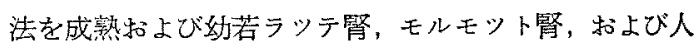
間の剔出腎にて追試，この染色法における動物個体差の ないことを確め，Häusler 法炕一部改良を加え，これ を蝸牛迷路厄和いて行い，モルモット血管帯の炭酸脱水 醅素を組織化学的に証明した。

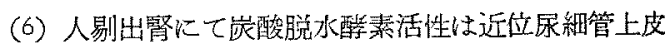
細䏗の遊離咳，才なるち，刷子縁と思はれる部位に認め た。

（7）内耳の物質代謝，分泌機構解明のための 1 つの方 法として acetazolamide 投与に上る内耳組織, 内耳液 の変動を観察し，内耳血管胃の特異性を認邓，末た内耳 血管带の炭酸脱水酵素の組織化学的証明を試み，その存 在を確認し，内耳物質代謝の基整的知見を得た。

\section{參考文献}

1) K. Wittmaack: Über die pathologisch-anat. u. pathphysi-Grundlagen der nichteitrige Erkrankungsprocesse des Inneren Ohres u. des Hörnervus. Archiv. für Ohr-usw. Heilkunde. 99. p. $71 \sim 136$, 1916. 2) Guild: The circulation of the Endolymph. Amer. J. Anat. 39, p. 57 81, $1927 . \quad 3)$ 3 川溞四郎：メ二ニル氏症候を呈せし患者の德㽞, 日耳 鼻, 44 巻, 12 号, 2310, 1938.4 4) Altman and Waltner: New investigation on the physiology of 
the labyrinthine fluids, Laryngoscope 60 , p. 912, 1950. 5) S. Rüedi: Some animal experiment findings on the functions of the inner ear, Annals of Oto. Vol 60, p. 993 1023, 1951.

6) E. Kley:

Zur Herkunft des Perilymph, Zeitschrift für Lary* ngo. 30, p. 486 502. 1951. 7) 内藤售他: $x=$ 工

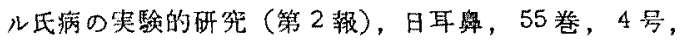
p. 234, 1952.8）吉田秀一：ピロカルピン及びアト ロピンのモルモット聴器述路に及ぼす影暗に関する実騟 的研器，日耳胃，55, p. 503 508, 1952.

9) J.E.

Hawkins, M.H. Lurie: The ototoxity of streptomycin, Annals of Oto Vol 61, p.789 809. 1952. 10) S.H. Mygind: Beiträge zur Physiologie der FlüBigkeitssysteme des Labyrinths, Archiv für O-N.K.H. 160. p. $472 \sim 500$. 1952. 11) H. Davis: Mechanism of Hearing, 1953. 12) Y. Kurata.: Histochemical demonstration of carbonic anhydrase activity, Stain technol. 28. p. $231 \sim 233$. 1953 . 13) C.A. Smith: The electrolytes of the labyrinthine fluids, Laryngoscope Vol 64. No. 3, p. 141 153, 1954.

Tasaki (H. Davis. \& D.H. Eldredge): J. Aconst. Soc. Amer. 26. p. $765 \sim 773.1954$. 15) J.G. Waltner: The chemical composition of perilymph in cats, Laryngoscope 64. 6. p. 439 453. 1954.

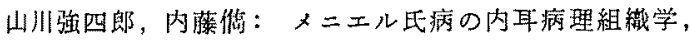
耳聯喉科，27(88)，p.820 839，1955. 17) D.C.

Pease: Infolded basal plasma membranes found in epithelium noted for their water transport, J. of Biophysical \& Biochem. Cytology. Vol. 2, 11, p.203, 1956. 18) $M$. Lawrence: Structures of the spiral prominence and external sulcus and their relation, Laryngoscope 66(7), p. 796 803. 1956.

19) 传旗

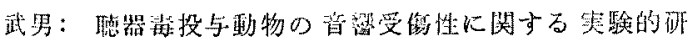
然，日耳鼠，60, 5, p. 479 495, 1957. 20) 荻地

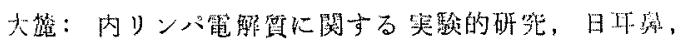
60,10, p. 1486 1493, 1957.

21) E. Borghesan.: Modality of the cochlear humoral circulation, Laryngoscpe 67. $121260 \sim 1285.1957 . \quad 22)$ C.A.

Smith:: Stucture of the stria vascularis and spiral prominence, Annals of Oto. 66. p.520, 1957.

H. Green, M.J. Mann, H.S. Kroman.: Elaboration of bicarbonate ion in intraocular fluids, Amer. J. of Oph. 44, p. 388 1957. 24) 阿部㭲：尿細管怡送

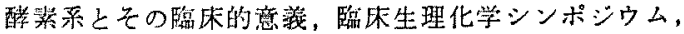
第, 2 集, p. $41 \sim 45,1958$. 25) 小林恒从。老人性難

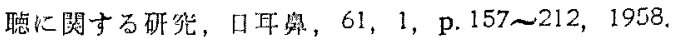

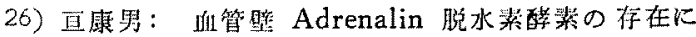
就いて, 大阪大学医学猚誌, 10,8, p.1075 1080, 1958. 27) K.H. Vosteen: Die Lokalisation verschiedener Atmungsfermente in der Schnecke, Archiv für Ohren-Nasen Kehlkopf usw. Heilkunde B. 171. p. 368 370. 1958. 28) K.H. Vosteen: Die Erschopfung der Phonoreceptoren nach funktioneller Belastung, Archiv für Ohren-Nasen-Kehlkopf-Heilkunde B. 172 , p. $489 \sim 512,1958$. 29) A.Koch and D.M. Woodburry.: Effects of carbonic anhydrase inhibition on brain excitability, J. of Pharmac and Experiment. therap. Vol. 122 , p. $335 \sim 342,1958 . \quad 30$ ) J. Gordon, Millichap, M, Balten, P. Hernandez.: Development of susceptibility to seizures in young animals. Brain water, electrolyte and acid-base metabolism, Proc. Soc. Exp. Biol. Med. 99 1, 6〜11, 1958, 31) L. Naftalin and M.S. Harrison.: Ciculation of labyrinthine fluids, J. of Laryngo. and Oto, 72, p. 118. 1958. 32) 阿南他: 生化学䒜験法,

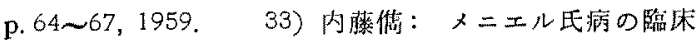
と病理，1959，日耳鵕総会，プソント 34) 苧川正

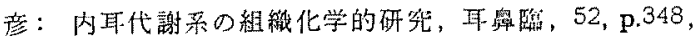
1959. 35) E. Borghesan:: Modality of the cochlear humoral circulation. Acta Oto-rhino-laryng. 10, p. $1266 \sim 1285,1959.30)$ D. Hennebert and $C$. Fernandez.: Ototoxicity of quinine in experimental animals, Archiv of Otolaryngology 70, 45, p.321 $\sim 333$, 1959. 37) H. Green, J.L. Sawyer,: Elaboration of bicarbonate-ion in intraocular fluids, Amer. J. of

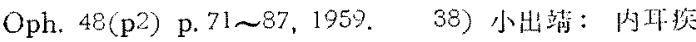

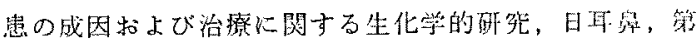

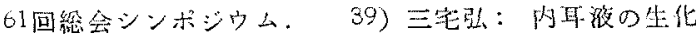
学について、日取、籍61回ンンポジウム。40）水

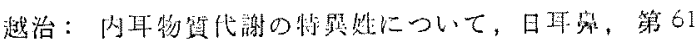

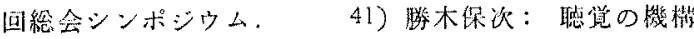
(1)，医学の好及，33，p.138〜144, 1960. 42) 䒠

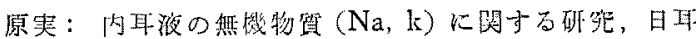

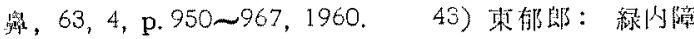

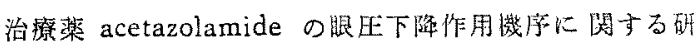

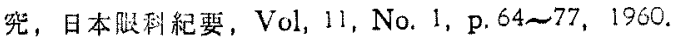




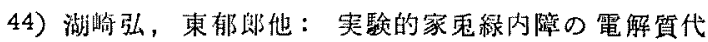

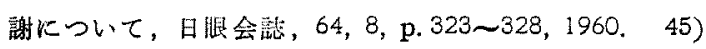

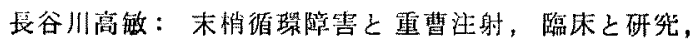
$37,6,828 \sim 832,1960.46)$ 方円正久: 酸装久乏の

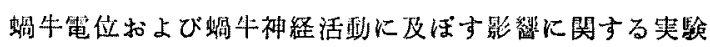

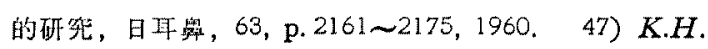
Vosteen.: The histochemistry of oxygen metololism in the inner ear, Laryngoscope 70, p. 351 362, 1960. 48) M. Lawrence, D. Wolsk, W.B. Litton.: Circulation of the inner ear fluids, Archiv of Oto. Vol 70. Numb. 3. p. 753 776, $1960 . \quad$ 49) Pease.: Histochemistry, 2nd Edition Churchill p. 597, 1960. 50) G.V. Bekesy: Experiments in hearing, 1960. 51) 陌間啓芳：局所てレルギ一反地による末梢血行障

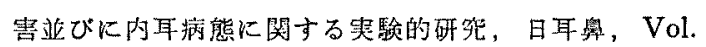
64. No. 3. p. 690 703, $1961 . \quad$ 52) H.L. Wullstein and S. Rauch.: Endolymph and Perilymph in Ménièris disease, Archiv. of Oto. Vol 73. Numb 3. p. $261 \sim 267,1961 . \quad$ 53) I. Kirikae et: A consideration on the circulation of the perilymph, Annals of Oto. Vol 70. Numb, 2. June 1961. 54) J.B. Jorgensen.: Changes of Aging in the inner ear, Archiv of Oto. Vol. 74, Numb, 2, p.164 171, 1961. 55) W.B. Litton \& M. Lawrence.: Electron microscopy in Méniére's disease, Archiv of Oto. Vol. 74, Numb 1. p. 32 39, 1961. 56) S.D. Erulkar and T.H. Maren.: Carbonic anhydrase and the inner ear, Nature Vol. 189, No. 4763, 1961. 57) K.H. Vosteen.: Neue Aspekte zur Biologie u. Pathologie des Innenohres, Archiv für Ohren-Nasen u. Heilkunde 178, Band 1. p. 1 104.1961. 58) 中村文蜼 他：内リンパ $\mathrm{Na}$ おび $\mathrm{K}$ イオンの螖牛電気現皱に

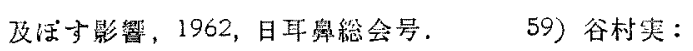

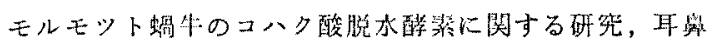
臨，54，8，p.814〜827，1962.60) 木村レイ：超音

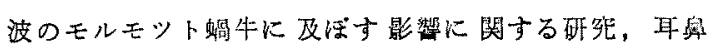

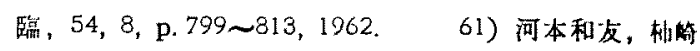
一郎：血管带汇おける呼吸醇絭汇関寸る研究，日耳. 年，65，p.179 183，1962. 62）安野友博：モル モットにおける Endocochlear potential に閉する夷 鈳的研究，日耳舅，65,2. p. 193 219, 1962. M.H. Maxwell, C.R. Kleeman.: Clinical disorders of fluid \& electrolyte metabolism, 1962. 64) D.H. Elderedge, C.A. Smith. H. Davis, R.P. Gannon.: The electrical polarization of the semicircular canals, Annals of Oto Vol 70 p. 1024 1037, 1962 , 65) S.Iurato:: The sensory cells of the membranous labyrinth, Archiv of Oto Vol 75, Numb. 4. p. 312 328. $1962 . \quad$ 66) G. Rossi.: L'acetylcholin esterase $\mathrm{Au}$ cours de development de L'oreille Interne du Cobaye, Acta Oto-laryngologie Suppl. 170. 1962. 67) E. Koburg u. D. Plaster.: Zur Grösse des Eiweissstoff wechsels der Gewebe der Cochlea, Acta Oto Vol 54. Fasc. 3〜4. p. 319 335, 1962, 68) Y. Yoshikawa, Y, Koide.: Some oxdizing enzymes in the cochlea, Annals of Oto Vol 71, Numb. 1. p.96 104, 1962. 69) S. Fujisaki. et.: Determ. ination of carbonic anhydrase. Medical J. of. Osaka University Vol. 12, No. 3〜4. p. 315 320, 1962.

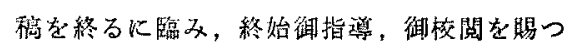
た恩師，度谷川高敏教授に㳭謝すると共に御援 助をいたよ゙いた，藤䗁俩師，佐藤博士，酒井博

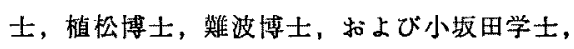
场井学士始め, 当教室锗先生および本学第一解 剖学教室前田敏博学士に深く謝意を表します。

本論文の要旨は第113回，第114回日本耳为

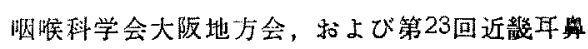
明喉科学会にて発表した。

（原椋到着=昭和 38.1.24 日） 


\section{渡部論文付図（I）}

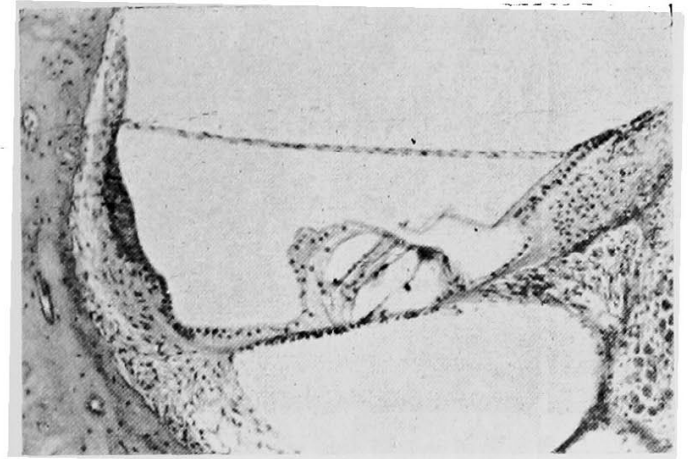

第 1 図正常モルモット蝸牛路 (第 3 回転) $10 \times 10$

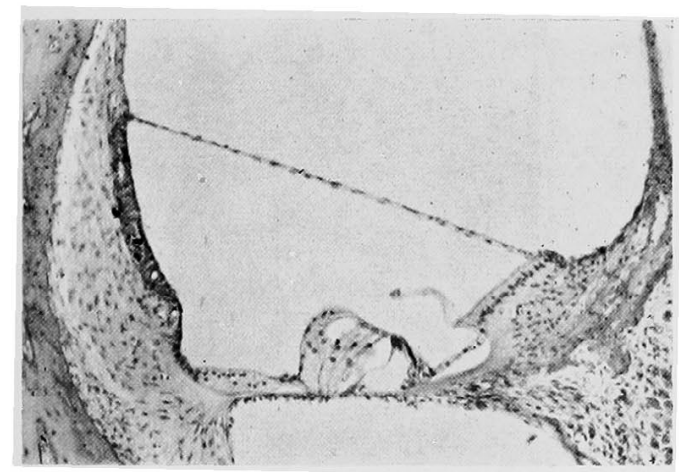

第 3 図正常モルモツト蝸牛迷路 (第 2 回䩓) $10 \times 10$

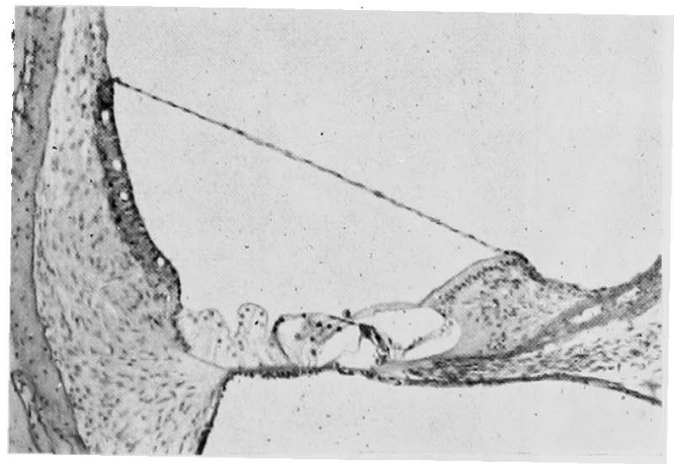

第 5 図正常モルモット蝸牛迷路 (第 1 回転) $10 \times 10$

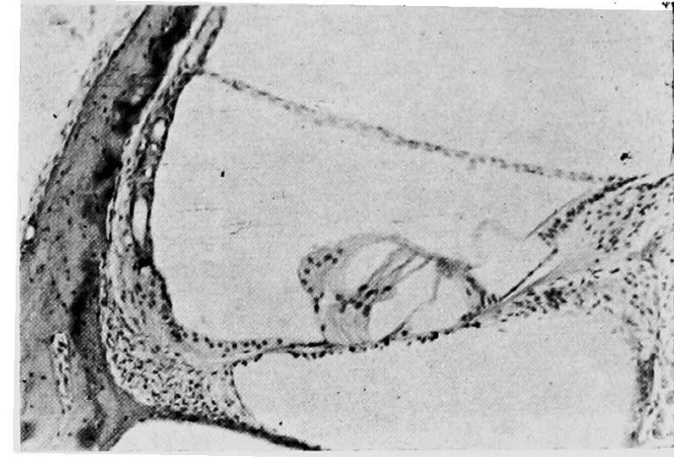

第 2 図 acetazolamide sodium $100 \mathrm{mg} / \mathrm{kg}$ 投与、1 時間後モルモツト蝛牛迷路 (第 3 回怯) $10 \times 10$

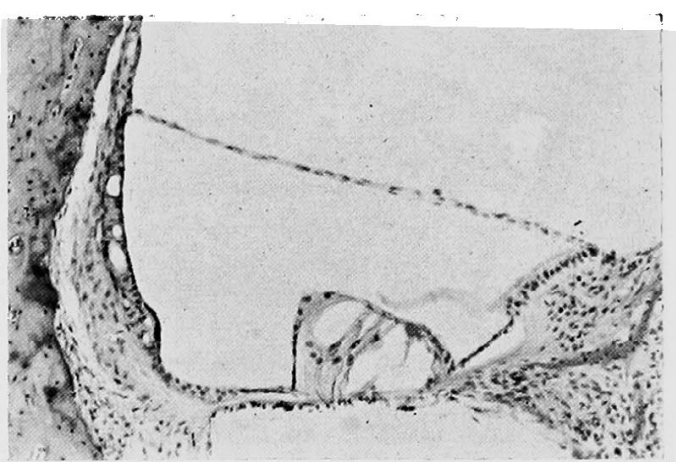

第 4 図 acetazolamide sodium $100 \mathrm{mg} / \mathrm{kg}$ 投与 1 時間後モルモット蝸牛迷路 (第 2 回転) $10 \times 10$

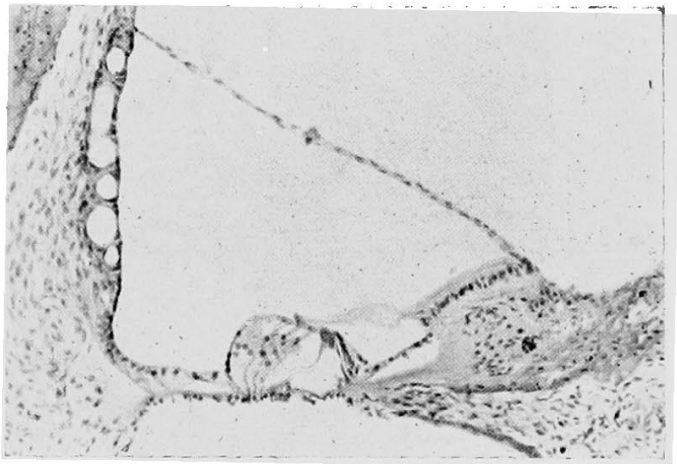

第 6 図 acetazolamide sodium $100 \mathrm{mg} / \mathrm{kg}$ 投与1時間後モルモツト蝸牛迷路 (第 1 回転) $10 \times 10$ 
渡部論 文付図（II）

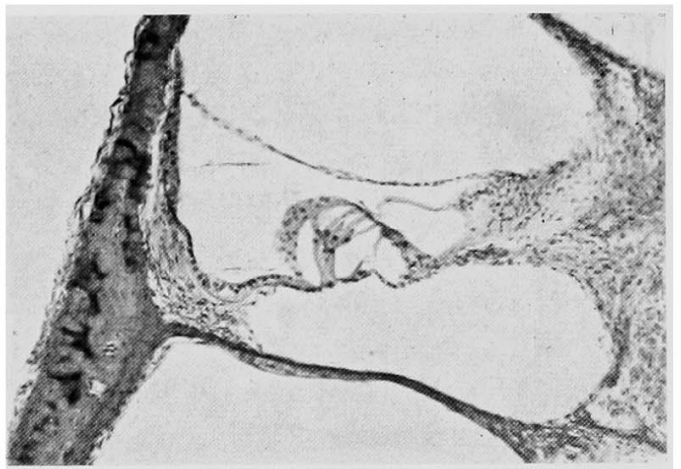

第 7 図 acetazolamıde scdıum iCOmg/ $\mathrm{kg}$ 投与12時間後，モルモット徭牛迷路 (第 3 回枟) $10 \times 10$

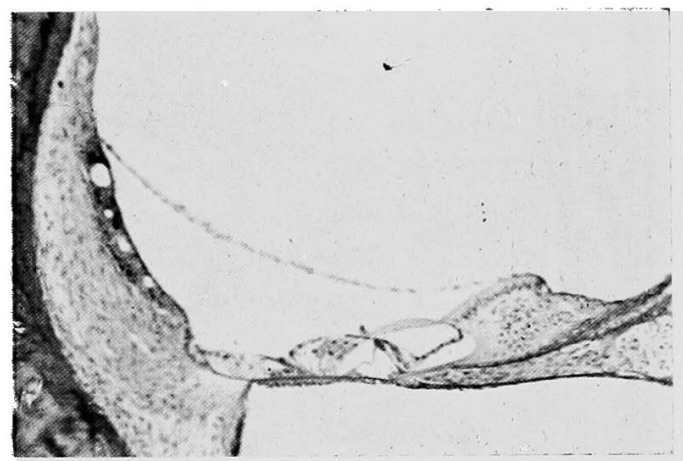
第 9 図 aceíazolamide sodium $100 \mathrm{mg} / \mathrm{kg}$
投与12時間後、モルモツト蚂牛迷路 (第 1 ２回枟）10以10

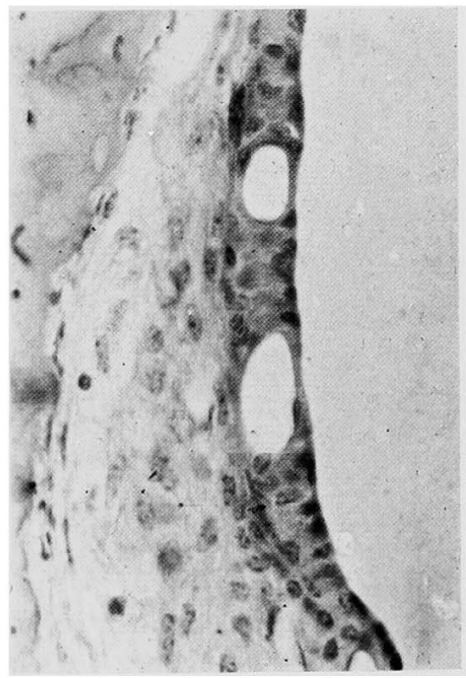

第 11 図 acetazolamide sodium $100 \mathrm{mg} / \mathrm{kg}$ 投与. 1 洔間後，血管帯第2回転 $10 \times 40$

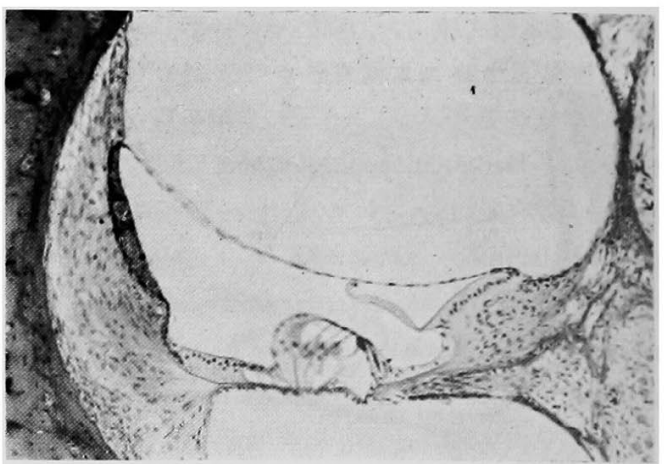

第 8 図 acetazolamide scdium $10 \mathrm{Cmg} / \mathrm{kg}$ 投与12時間後，モルモツ!䅞牛迷路 (第 2 回転) $10 \times 10$

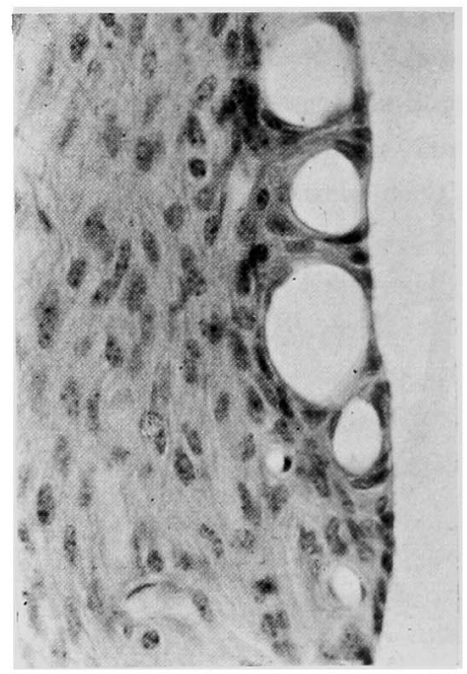

第 10 図 acetazolamide scdium $100 \mathrm{mg} / \mathrm{kg}$ 投 与 1 時間後血管带, 第 1 回転 $10 \times 40$

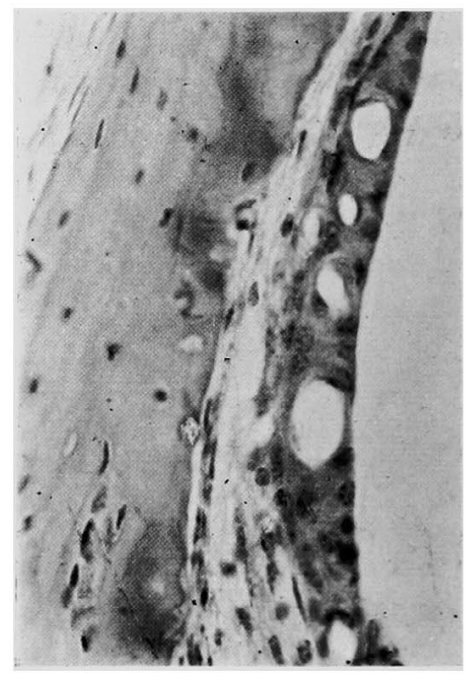

第 12 図 acetazolamide sodium $100 \mathrm{mg} / \mathrm{kg}$ 投与 1 時間後，血管带第3回転10×40 


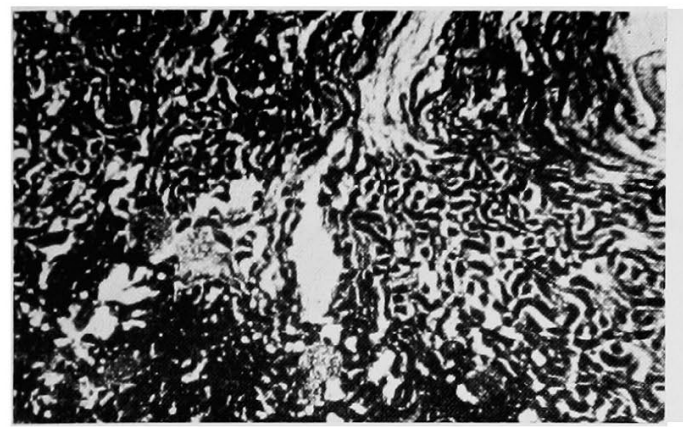

第 13 図 ラッテ腎組織の炭酸脱水酵素 (Häusler 法) $10 \times 10$

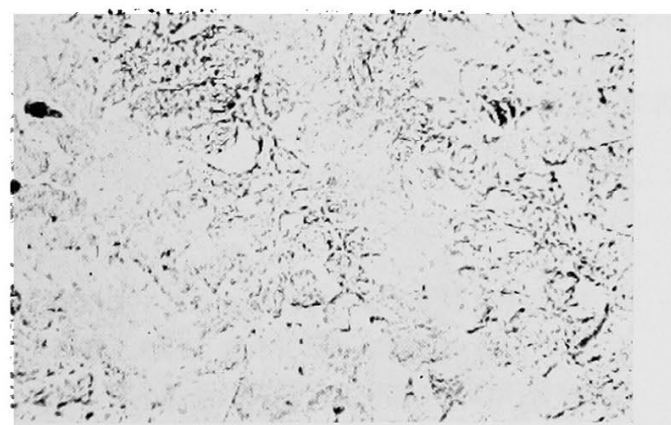

第 15 図 ラッテ腎組織 (Häusler 変法) acetazolamide sodium

$4 \times 10^{-3} \mathrm{~mol}$ にて抑制 $10 \times 10$

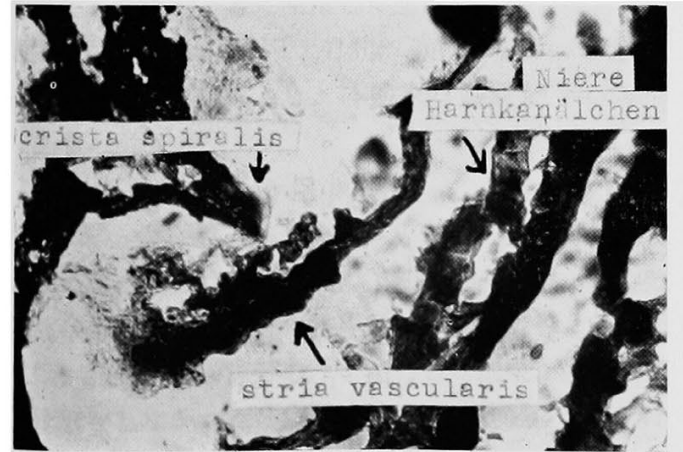

第 17 図モルモツト䖮牛迷路炭酸脱水醉素 (Häusler 変法) $10 \times 10$

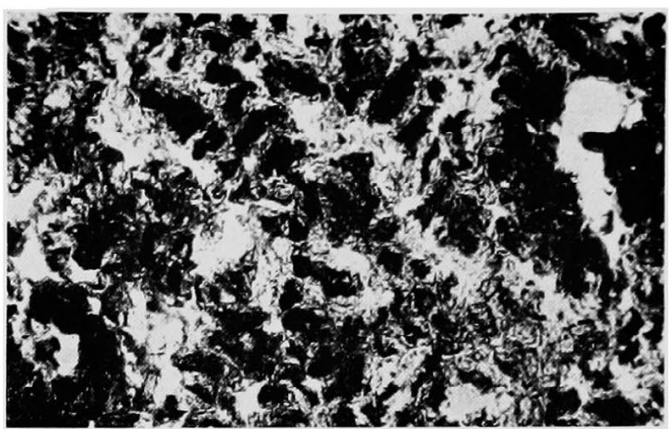

第 14 図 ラッテ緊組織の炭酸脱水酵素 (Häusler 変法) $10 \times 40$

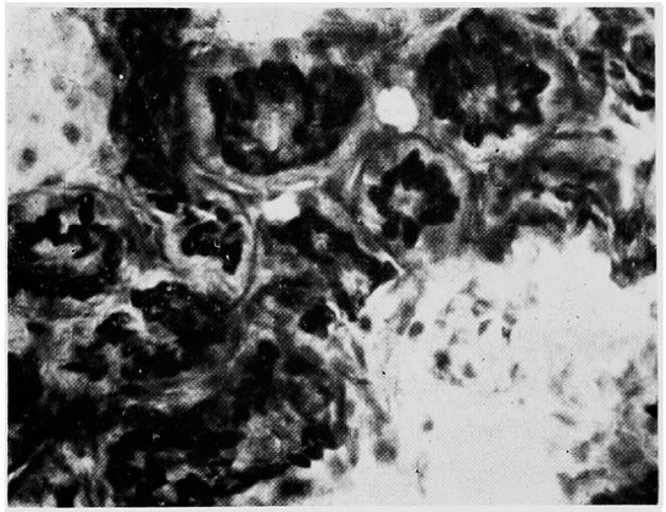

第 16 図人剔出腎，尿細管炭酸脱水酵素 (Häusler 変法) $10 \times 40$

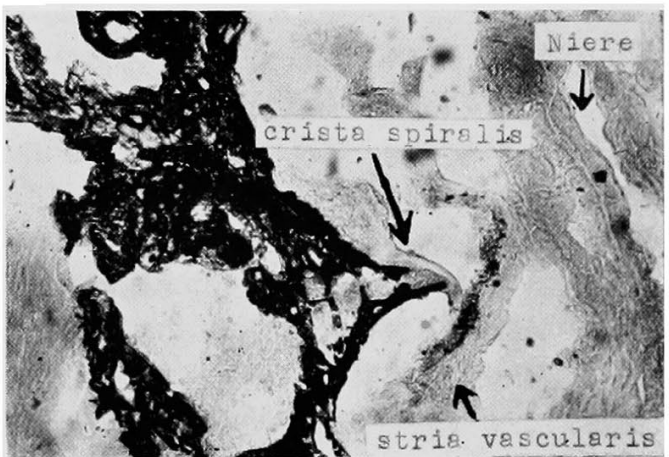

第:18図モルモツト蝸牛迷路 acetazolamide sodium $4 \times 10^{-3} \mathrm{~mol}$ にて抑制 $10 \times 10$ 